\title{
Quality of carrots as affected by pre- and postharvest factors and processing
}

\author{
Randi Seljåsen, ${ }^{a *}$ Hanne L Kristensen, ${ }^{b}$ Charlotte Lauridsen, ${ }^{c}$ \\ Gabriela S Wyss, ${ }^{d+}$ Ursula Kretzschmar, ${ }^{d \neq}$ Inès Birlouez-Aragone ${ }^{e}$ \\ and Johannes Kahl ${ }^{f}$
}

\begin{abstract}
The aim of this review is to provide an update on factors contributing to quality of carrots, with special focus on the role of pre- and postharvest factors and processing. The genetic factor shows the highest impact on quality variables in carrots, causing a 7-11-fold difference between varieties in content of terpenes, $\beta$-carotene, magnesium, iron and phenolics as well as a 1-4-fold difference in falcarindiol, bitter taste and sweet taste. Climate-related factors may cause a difference of up to 20-fold for terpenes, $\mathbf{8 2} \%$ for total sugars and $30-40 \%$ for $\beta$-carotene, sweet taste and bitter taste. Organic farming in comparison with conventional farming has shown $\mathbf{7 0} \%$ higher levels for magnesium and $\mathbf{1 0 \%}$ for iron. Low nitrogen fertilisation level may cause up to $100 \%$ increase in terpene content, minor increase in dry matter $(+4$ to $+6 \%)$ and magnesium (+8\%) and reduction in $\beta$-carotene content $(-8$ to $-11 \%)$. Retail storage at room temperature causes the highest reduction in $\beta$-carotene $(-70 \%)$ and ascorbic acid $(-70 \%)$. Heat processing by boiling reduces shear force $(-300$ to $-1000 \%)$ and crispiness $(-67 \%)$ as well as content of phenolics $(-150 \%)$, terpenes $(-85 \%)$ and total carotenes $(-20 \%)$ and increases the risk of furan accumulation. Sensory and chemical quality parameters of carrots are determined mainly by genetic and climate-related factors and to a minor extent by cultivation method. Retail temperature and storage atmosphere as well as heating procedure in processing have the highest impact in quality reduction.
\end{abstract}

(c) 2013 Society of Chemical Industry

Keywords: carrot; Daucus carota; quality; preharvest; postharvest; heat processing

\section{INTRODUCTION}

The study of carrot quality in the 1950s was focused on sensory quality, with main emphasis on the bitter taste. ${ }^{1,2}$ At the beginning of the 1980s the so-called hash flavour associated with the strong burning flavour of turpentine was given high priority in the study of carrot varieties. ${ }^{3}$ During this period, attention was also given to $\beta$-carotene as a health constituent with effect against human cancer, as reviewed by Peto et al. ${ }^{4}$ Lately, the study of health effects of polyacetylenes such as falcarinol and falcarindiol has attracted most attention concerning health aspects of carrots. 5,6

Carrot is very sensitive with respect to influences by biotic and abiotic stress on quality characteristics. During the entire production chain, from seed to consumption, carrots are exposed to abiotic and biotic factors that affect the quality in different directions. The genetic factor gives the initial code for the level of important chemical compounds involved in sensory and health-related aspects of carrots. ${ }^{7-13}$ Furthermore, climatic factors such as temperature and precipitation, 7,14,15 farming system (organic versus conventional), ${ }^{15-17}$ fertilisation status, uptake of constituents present in soil ${ }^{18-20}$ as well as postharvest handling ${ }^{21,22}$ and processing factors such as heat treatment ${ }^{23,24}$ affect the sensory quality of carrots.

The aim of this review is to provide an update of the last three decades on factors contributing to quality of carrots, with special focus on the role of pre- and postharvest factors and processing on the enhancement of and detraction from quality characteristics of carrots. The review deals with important aspects

\footnotetext{
* Corresponding Author: Randi Seljåsen, Bioforsk Norwegian Institute for Agricultural and Environmental Research, Reddalsveien 215, NO-4886, Grimstad, Norway. E-mail: randi.seljasen@bioforsk.no

† Current address: Grün Stadt Zürich, Sukkulenten-Sammlung Zürich, Mythenquai 88, CH-8002 Zürich, Switzerland

‡ Current address: Oberebnetstrasse 11, CH-5073 Gipf-Oberfrick, Switzerland

a Bioforsk Norwegian Institute for Agricultural and Environmental Research, Reddalsveien 215, NO-4886 Grimstad, Norway

b Department of Food Science, Aarhus University, Kirstinebjergvej 10, DK-5792 Aarslev, Denmark

c Department of Animal Science, Aarhus University, Blichers Alle 20, PO Box 50, DK-8830 Tjele, Denmark

d Research Institute of Organic Agriculture, Unit of Food Quality and Safety, Ackerstrasse, Postfach, CH-5070 Frick, Switzerland

e Spectralys Innovation, BIOCITECH, 102 avenue Gaston Roussel, 93230, ROMAINVILLE, France

f Department of Organic Agriculture, University of Kassel, Nordbahnhofstraße
} 1a, D-37213 Witzenhausen, Germany 
of quality control and makes it possible to compare results from the literature on the different factors affecting quality. This is done by examples from the literature on reported differences in quality characteristics (significance level $P \leq 0.05$ ). To allow comparison of results from descriptive sensory analyses using different scales from $a$ to $b$, the score results from diverse studies are converted to a uniform scale with gradation from $c(=1$, low intensity) to $d$ ( $=9$, high intensity). The transformation is done by the function

$$
y=d[(x-a) /(b-a)]+c[(b-x) /(b-a)]
$$

where $x$ is the given score value measured within the scale interval $a$ to $b$.

Calculations of percentage difference, increase or decrease are presented to facilitate comparisons. Differences between highest and lowest values are calculated as percentage of lowest value. In cases where an increase is described, this is indicated by plus $(+)$ and the percentage is calculated from the lowest value. Similarly, reduction is indicated by minus ( - ) and the percentage is calculated from the highest value.

Most of the studies included in this review deal with orangecoloured varieties, but different-coloured varieties are mentioned where actual studies are published. Where no other information is given, the presented studies are from orange-coloured carrot varieties.

\section{QUALITY-AFFECTING FACTORS}

Quality properties of carrots are investigated by the aspects 'food safety', 'nutritional value', 'health value', 'sensory quality' and 'shelf life'.

The factors affecting these quality aspects are divided into groups according to occurrence preharvest, postharvest or during processing. The first preharvest steps are mainly quality-building measures during growth and development of the plants in the field. Of these, the choice of variety is the most important factor for potential quality. After harvest of the carrots the critical operations are handling, storage and sometimes processing. During the production chain the possibility to trace irregularities in handling that compromise quality can be difficult. This demands a need for detailed control and documentation of the production chain. There has been evidence that certain labelled products, e.g. 'sweet snack carrots' or 'organic carrots', were believed to possess superior quality compared with bulk products. However, such a quality difference is difficult to guarantee. The initial quality at harvest can be changed during handling, storage or processing. The impact of different factors on the defined quality aspects is summarised by grouping actual studies in Tables 1-3. These factors are described in the preharvest, postharvest and processing sections below.

\section{PREHARVEST FACTORS INFLUENCING QUALITY}

During growth and development of carrots, quality can be affected from sowing to harvest by (1) general preharvest factors such as genetic variation and climatic conditions (light, temperature, precipitation) as well as (2) farming system-related factors that deal with organic or conventional cultivation systems, fertilisation and pest control (Table 1). In the following subsections the preharvest factor contributions to differences in content of chemical compounds or sensory quality are discussed.

\section{General preharvest factors}

\section{Variety}

The genetic background seems to be the most important factor under human control in modifying the nutritional and health aspects as well as sensory aspects of carrots. A large number of quality characteristics, especially aroma components such as terpenes, sugars, $7,9,25$ nutrients and possible healthrelated compounds such as carotenes and falcarinol, seem to be genetically determined. ${ }^{9,51,52}$

The aroma components terpinolene and caryophyllene showed particularly high variation within the open-pollinated orange variety 'Imperator', with 630 and 502\% differences respectively. ${ }^{7}$ For an inbred orange line ('B10138'), differences were 23\% for terpinolene and $50 \%$ for caryophyllene between varieties with lowest and highest contents. ${ }^{7}$ Particularly high variation was detected between varieties for terpinolene, with $650 \%$ difference between the extremes 'Imperator' $\left(0.8 \mathrm{mg} \mathrm{kg}^{-1}\right.$ fresh weight (FW)) and 'Nantes' ( $\left.6.0 \mathrm{mg} \mathrm{kg}^{-1} \mathrm{FW}\right) .{ }^{11}$ Similarly, caryophyllene varied by $730 \%$ between 'Oregon' ( $1.2 \mathrm{mg} \mathrm{kg}^{-1} \mathrm{FW}$ ) and 'Nantes' (10 mg $\left.\mathrm{kg}^{-1} \mathrm{FW}\right) .{ }^{11}$ High variation in terpene content between cultivars was also confirmed by Simon and Peterson ${ }^{7}$ for $\alpha$-phellandrene, limonene and terpinolene.

Sugar content differed between varieties from 45 to $72 \mathrm{mg} \mathrm{g}^{-1}$ FW $(60 \%)^{7}$ and from 26 to $62 \mathrm{mg} \mathrm{g}^{-1} \mathrm{FW}(138 \%)$ in a study by Bajaj et al. ${ }^{9}$ (for 'Nantes' and a yellow carrot cultivar respectively). Of the sugars, sucrose content exhibited the highest variation between orange varieties, showing a 300\% difference between highest and lowest levels when comparing five inbred lines. ${ }^{7}$ Sensory score for sweet taste varied between varieties from 4.4 to 6.1 (39\%) when transformed to the 1-9-point scale. ${ }^{7}$ Similar differences in sensory scores varied between genotypes from 3.8 to 6.8 for sweet taste (79\%), from 2.7 to 4.6 for bitter taste $(70 \%)$, from 5.3 to 6.3 for carrot flavour (19\%) and from 6.6 to 7.6 for hardness (15\%). ${ }^{13}$ Bardseth et al. ${ }^{25}$ found variation in sensory scores between the carrot cultivars 'Merida', 'Fontana', 'Newburg' and 'Nandrin' for sweet taste (from 5.2 to 5.5, 6\%), bitter taste (from 2.4 to $2.9,21 \%$ ), juiciness and crispiness (both varied from 5.0 to $5.9,18 \%)$

Sensory scores differed by $55 \%$ for bitter taste, $54 \%$ for sweet taste and $11 \%$ for carrot flavour between the orange varieties 'Nottingham', 'Tornardo', 'Bolero' and 'Nairobu'. ${ }^{12}$ When differentcoloured varieties were included, there were 119 and 209\% differences between the varieties with lowest and highest sensory scores for sweet taste and bitter taste respectively. ${ }^{12}$

Nutritional value as measured by mineral content also differed between 23 varieties of different colours by $370 \%$ for manganese (1.1-5.2 $\left.\mu \mathrm{g} \mathrm{g}^{-1} \mathrm{FW}\right), 294 \%$ for iron (12.3-48.5 $\left.\mu \mathrm{g} \mathrm{g}^{-1} \mathrm{FW}\right)$ and $108 \%$ for potassium $\left(1990-4140 \mu \mathrm{g} \mathrm{g}^{-1} \mathrm{FW}\right){ }^{9}$ Content of $\beta$ carotene varied by $900 \%$ when a yellow carrot $\left(0.85 \mu \mathrm{g} \mathrm{g}^{-1} \mathrm{FW}\right)$ was compared with an orange type ( $\left.\mathrm{Nr} 10-75 \mathrm{~A}, 85 \mu \mathrm{g} \mathrm{g}^{-1} \mathrm{FW}\right){ }^{9}$ Alasalvar et al. ${ }^{8}$ found $120-130 \%$ higher $\alpha$-and $\beta$-carotene levels in purple carrots compared with orange varieties, only trace amounts in yellow types and no carotene in white varieties. Similar results were reported by Metzger et al. ${ }^{10}$

Content of health-related phenolics differed more than 10-fold (1127\%) between varieties of different colours as determined for $5^{\prime}$-caffeoylquinic acid, which varied from $44 \mu \mathrm{g} \mathrm{g}^{-1} \mathrm{FW}$ (yellow and white varieties) and $85 \mu^{-1} \mathrm{~g} \mathrm{~g}^{-1} \mathrm{FW}$ (orange variety) to $540 \mu \mathrm{g}$ $\mathrm{g}^{-1} \mathrm{FW}$ (purple variety). ${ }^{8}$ Falcarinol content differed up to $430 \%$ between white and purple varieties (from 0.3 to $1.6 \mu \mathrm{g} \mathrm{g}^{-1}$ dry weight (DW)), while an orange-coloured sample was intermediate in level $\left(0.6 \mu \mathrm{g} \mathrm{g}^{-1} \mathrm{DW}\right){ }^{10}$ 

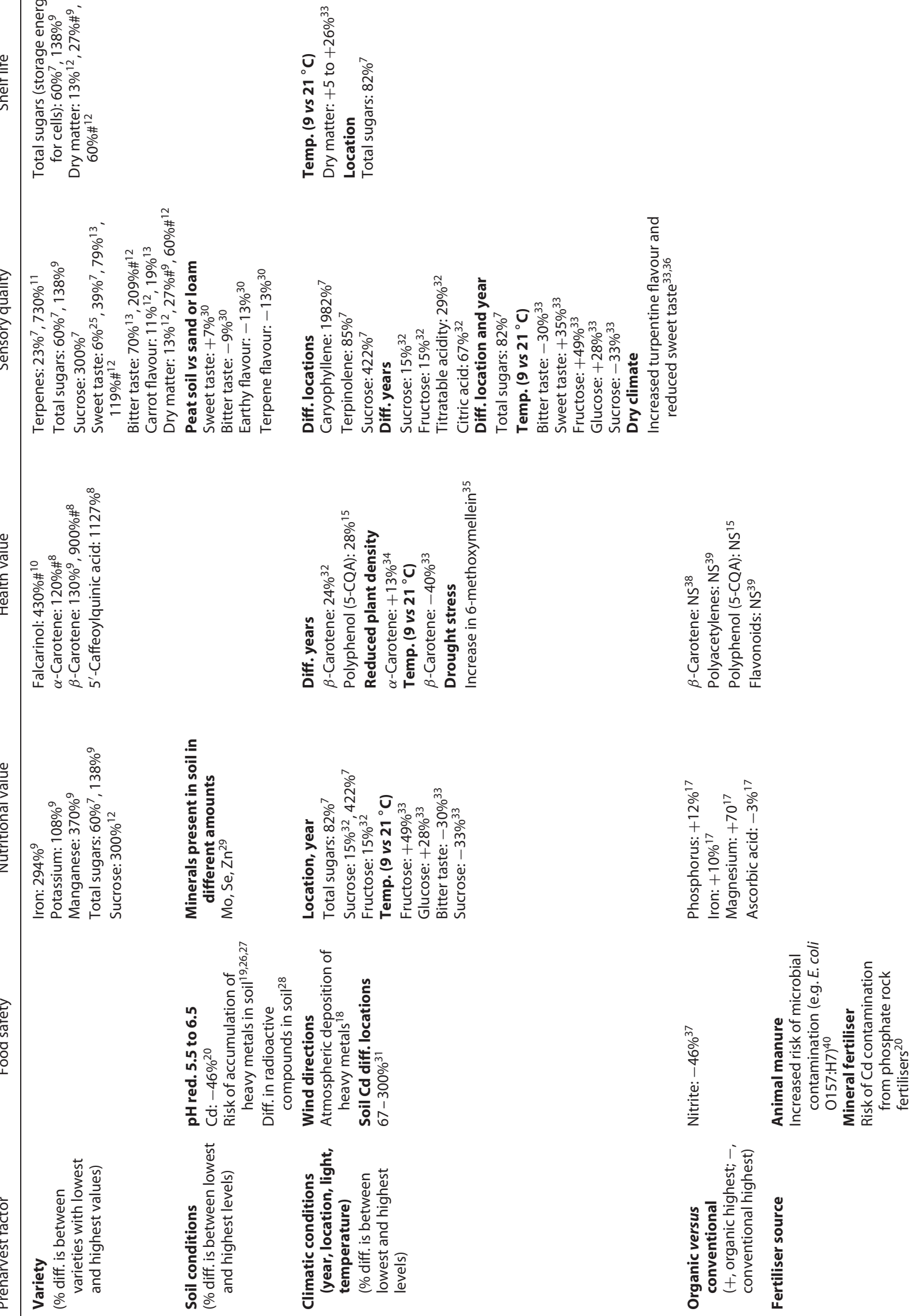


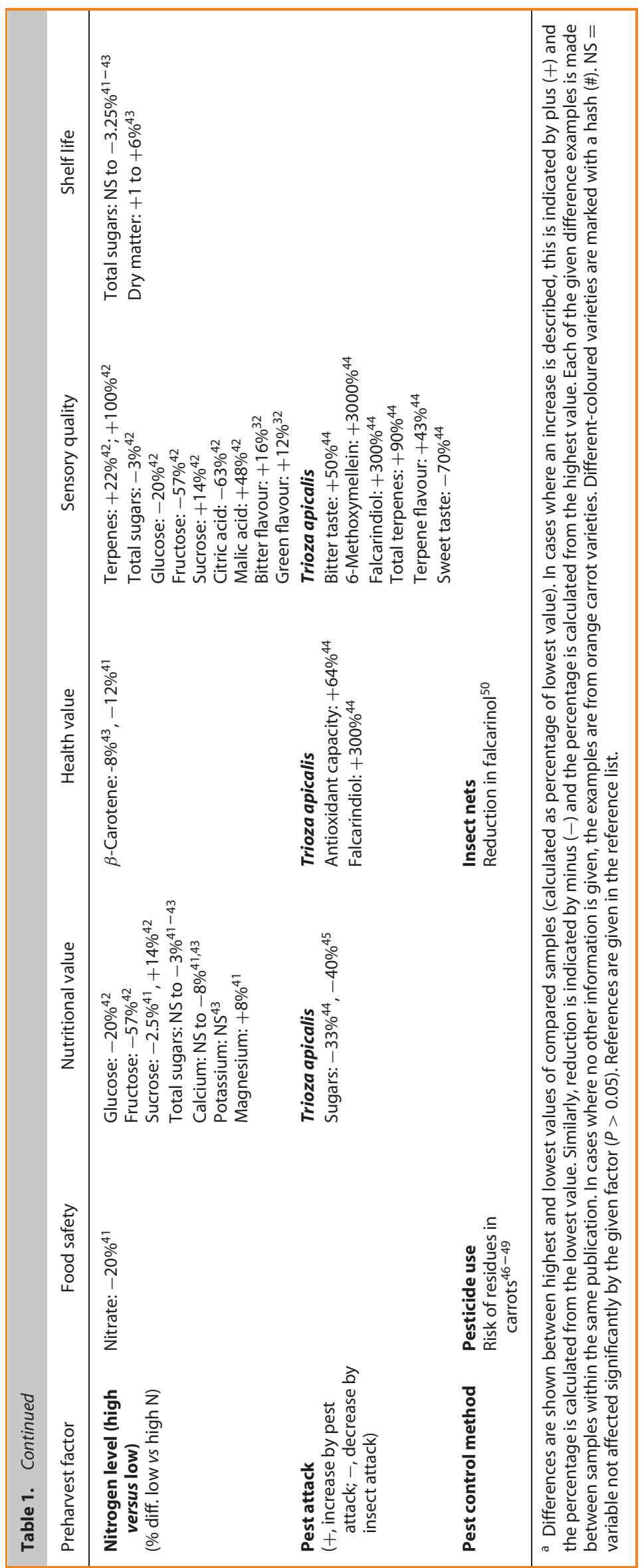


The variety also affects dry matter (DM) content. The percentage differences in DM between lowest and highest contents in a study of varieties by Kreuzmann et al. ${ }^{12}$ were $13 \%$ for orange-coloured varieties (from $10.5 \%$ DM for 'Soprano' to $11.8 \%$ DM for 'Bolero') and $60 \%$ for mixed colours (from 9.1\% DM for 'White Satin' to $14.6 \%$ DM for 'Purple Haze'). Carrots of mixed colours in a study by Bajaj et al. ${ }^{9}$ showed $27 \%$ difference in DM between the cultivars with highest and lowest levels (from 8.8\% DM for 'Sel. 5a' to $11.2 \%$ DM for 'Kurna').

High-yielding carrot varieties are often chosen for industrial processing. However, in general, these varieties may have less appealing sensory characteristics. This is exemplified in a comparison study that revealed higher content of descriptors having negative impact on the perceived quality (such as bitter taste, soil flavour, terpene flavour, green odour, astringency or toughness) for the traditional industry variety 'Fontana' in comparison with the fresh market variety 'Natalja', which showed more positively associated sensory variables such as sweet taste, sourness, juiciness and crispness. ${ }^{30,53}$ To a certain extent, bitter taste and toughness can be minimised by processing, ${ }^{54}$ so these high-yielding varieties can to some extent be used in processed products.

\section{Soil conditions}

Carrots and other plants not only accumulate nutrients from fertiliser added to soil, they also accumulate trace elements and heavy metals released from soil particles. ${ }^{19,26}$ Toxic compounds such as mercury and other heavy metals ${ }^{19,26}$ and radioactive compounds (radionuclides) ${ }^{28}$ may accumulate when present in soil and thereby affect the safety aspect of carrots. Cadmium is one such compound that easily accumulates in carrots from contaminated soil. ${ }^{27}$ Higher cadmium accumulation levels were detected in carrots than in radish by Zheng et al. ${ }^{27}$ Levels of cadmium in European carrots vary from $0.024 \mathrm{mg} \mathrm{kg}^{-1} \mathrm{DM}$ in Finland to $0.040 \mathrm{mg} \mathrm{kg}^{-1} \mathrm{DM}$ in the Netherlands (67\%) as compared with $0.028 \mathrm{mg} \mathrm{kg}^{-1} \mathrm{DM}$ in the USA. ${ }^{31}$ Cadmium levels in carrots grown in different areas of Sweden varied from $0.12 \mathrm{mg} \mathrm{kg}^{-1} \mathrm{DM}$ in Gotland County to $0.48 \mathrm{mg} \mathrm{kg}^{-1} \mathrm{DM}$ in Malmöhus County (300\%). ${ }^{31}$ Accumulation of cadmium may be caused by atmospheric deposition of heavy metals, ${ }^{18}$ polluted soils or rock material as a natural constituent of soil. The element can also be added by conventional mineral fertilisers (bound to phosphorus), sludge ${ }^{19}$ from animal production as well compost ${ }^{26}$ or phosphate rock fertilisers, ${ }^{20}$ which may be used in both organic and conventional farming.

The $\mathrm{pH}$ level influences the availability of trace elements essential for carrot growth, but also other trace elements such as nickel and zinc as well as selenium that are not necessary for growth and development of the plant. ${ }^{55}$ Lowering the $\mathrm{pH}$ decreases the uptake of selenium and increases the accumulation of other trace elements such as copper, nickel and zinc. In a Swedish study, $76-85 \%$ of the variation in cadmium content in carrots could be explained by $\mathrm{pH}$, organic matter content and cadmium and zinc content in soil at harvest. ${ }^{31}$ Cadmium accumulation was found to be up to $46 \%$ higher at $\mathrm{pH} 5.5$ compared with $\mathrm{pH} 6.5 .^{20}$ Thus adjustment of $\mathrm{pH}$ to 6.5 is preferable to ensure both safety and health aspects.

The soil composition (soil class) may to some extent affect sensory quality of carrots. In comparison with loam and sand soils, which not differed in sensory characteristics, growing of carrots in peat soil yielded $7 \%$ higher score for sweet taste (4.6 vs 4.3) and $4 \%$ higher for juiciness ( 5.3 vs 5.1 ) when means were compared. ${ }^{30}$
The score for bitter taste was $9 \%$ lower in peat soil (4.0) compared with loam and sand soils (mean 4.4). Similar reductions for peat soil were found for earthy flavour (-13\%) and terpene flavour (-13\%) in comparison with sand and loam soils. ${ }^{30}$ The effect of peat on sweet taste can be explained in part by the lower soil temperature measured in peat soil, which may increase sugar content as seen in other studies. ${ }^{33,56,57}$

\section{Climatic conditions and irrigation}

The effect of year and location on the quality aspect pertains to annual or local variations in climatic conditions such as precipitation and temperature, but also variations in pest attack. With the exception of water supply, which can be increased by irrigation, these factors are outside the control of the farmer.

When comparing different locations (Florida and Texas, F1 hybrids), typical 50-100\% differences were found in single terpenes, while total sugars differed by only $10 \%(42-46 \mathrm{mg}$ $\left.\mathrm{g}^{-1} \quad \mathrm{FW}\right){ }^{7}$ However, climatic variation indicated by location and year can be much higher. An inbred line grown at four locations over two years showed a dramatic difference between locations and years in content of caryophyllene (1982\%) as well as for terpinolene (85\%), sucrose $(422 \%)$ and total sugars $(82 \%){ }^{7}$ Differences between years (28\%) were found for content of 5-Ocaffeoylquinic acid, which accounts for $80 \%$ of the total phenol content in carrots. ${ }^{15}$ Differences between years were also seen in a study by Paoletti et al..$^{32}$ on the content of sugars (3\% for glucose and $15 \%$ for fructose and sucrose content), $\beta$-carotene (24\%) and acids (fumaric acid $25 \%$, citric acid $67 \%$, titratable acidity 29\%).

Water availability is very important to the growth and healthiness of carrots. Precipitation and irrigation influence the availability and uptake of nutrients from soil in the same manner. Stress from high or low water content in soil can reduce growth and yield and induce the production of undesirable compounds in carrots. ${ }^{58,59}$ Drought stress is known to increase ethylene production and 6-methoxymellein in carrots ${ }^{35,60}$ as well as acetaldehyde and ethanol in other plants. ${ }^{58}$

Besides precipitation, temperature and light conditions are the most important climatic factors. A warm, humid climate seems to affect the sensory quality by creating stronger turpentineflavoured and less sweet-tasting carrots than a cooler, dry climate. $^{33,36}$ It has been shown that low cultivation temperature (9 vs $21^{\circ} \mathrm{C}$ ) affects the sensory aspect by increasing sweet taste $(+35 \%)$ and content of fructose $(+49 \%)$ and glucose $(+28 \%)$ and reducing bitter taste $(-30 \%)$ and content of sucrose $(-33 \%)$ and $\beta$-carotene $(-40 \%)$ (mean of four cultivation periods in phytotron). ${ }^{33} \mathrm{DM}$ content varied for different cultivation periods by +5 to $+26 \%$ when cultivation at $21{ }^{\circ} \mathrm{C}$ was compared with that at $9{ }^{\circ} \mathrm{C} .{ }^{33}$

The $\alpha$-carotene content in carrots was found to be higher (+13\%) with a low plant density ( $18 \mathrm{mg} \mathrm{kg}^{-1} \mathrm{FW}$ for 400000 plants ha ${ }^{-1}$ ) than with a high plant density $\left(16 \mathrm{mg} \mathrm{kg}^{-1} \mathrm{FW}\right.$ for 700000 plants $\left.\mathrm{ha}^{-1}\right) .^{34}$ This can be explained by an increase in UV radiation to the plants and the fact that carotenoids act as photoprotection compounds in the photosynthetic function. ${ }^{61}$ This indicates that growing seasons with a high intensity of UV light may cause an increase in carotene content of carrots.

Also, wind stress has been shown to increase the DM in carrots, while at the same time decreasing the concentration of phosphorus, magnesium, sodium and calcium. ${ }^{62}$ 


\section{Effect of preharvest factors related to farming system (conventional or organic)}

Comparison of organic and conventional systems

The farming system consists of certain quality-affecting factors in which fertilisation and pest treatment methods are the main differences between organic and conventional systems. In this part of the review, studies that compare conventional and organic farming systems will be presented. This is done by a general organic versus conventional comparison, and thereafter in subsections that focus on specific factors that can be varied within the systems (fertilisation, pest treatment method).

Owing to consumer willingness to pay extra for organic products, the possible differences between organic and conventional products in regard to the aspects of nutritional and health-promoting value are important. ${ }^{63-66}$ Studies that attempt to demonstrate differences between organic and conventional foods can be divided into three groups: (1) studies that measure the 'nutritional composition' of foods that are organically versus conventionally produced; (2) studies that consider the 'healthpromoting effects' of organically versus conventionally produced foods (including measurement of secondary metabolites and other substances that may be of interest with regard to health promotion); (3) animal feeding and human intervention studies that include the measurement of 'health status'.

Studies assigned to the first group show small and inconsistent differences between organic and conventional farming systems. ${ }^{67,68}$ However, in most of these studies, only macronutrients, vitamins and minerals were analysed and secondary metabolites were not determined. The levels of secondary plant compounds might be enhanced in organic products because of a diminished input of nitrogen. ${ }^{41,50,69}$ In the reviews by Worthingon ${ }^{17}$ and Rembialkowska ${ }^{70}$ it is concluded that a variety of different organic crops have a higher content of phenolics $(+119 \%)$ and vitamin $C(+29 \%)$ as well as magnesium $(+29 \%)$ and iron $(+21 \%)$. Studies allocated to the second group make the assumption that differences in the concentration of vitamins and secondary metabolites translate into a perceived health benefit, although for many compounds there are no available data in this area to justify this assumption. The third group of investigations has been associated with difficulties in the choice of health markers, as the term 'health' has a very broad definition, and the data available from such studies are generally sparse and often limited by a lack of replication in the farming systems. $^{71}$

There are in general very few studies that have compared the content of secondary plant metabolites from different cropping systems under comparable field conditions. A recent metaanalysis ${ }^{72}$ reviewed original papers published on organic versus conventional cultivation. The content of secondary metabolites in fruits and vegetables was $12 \%$ higher in organic products compared with conventional products. ${ }^{72}$ However, of the studied components, only the carotenes are relevant for carrots, and they were not affected by the cultivation system.

Organic vegetables have in some studies shown a higher content of nutrients and secondary compounds compared with conventionally grown products. ${ }^{17,73}$ In the review by Worthington, ${ }^{17}$ statistical methods were used to identify significant differences and trends in published studies comparing nutrient contents of organic and conventional crops. The results show $10 \%$ more iron, $12 \%$ more phosphorus, $70 \%$ more magnesium and $3 \%$ less ascorbic acid in organic compared with conventional carrots. Carotenes (lutein, $\alpha$-carotene, $\beta$-carotene) seem to decrease ${ }^{50}$ or remain unaffected by organic farming compared with conventional cultivation. ${ }^{38}$ Similarly, there were no differences between conventional and organic farming systems in content of the polyacetylenes falcarinol, falcarindiol and falcarindiol3 -acetate ${ }^{39}$ and the common phenolic acid 5-O-caffeoylquinic acid. ${ }^{15}$

Only a limited number of studies make direct comparisons of the bioavailability of individual nutrients from the same food products produced by organic and conventional systems. ${ }^{74}$ In a human intervention study, no differences between the two systems were found on the bioavailability of carotenoids, antioxidant effect and antigenotoxic or immunological effects in healthy subjects after carrot consumption. ${ }^{75}$ Similarly, in a rat study, no effects on the bioavailability of major and trace minerals were detected. The rats were fed, among other foods, dried carrots grown from two consecutive years in farming systems with high or low fertilisation, with and without pesticides. ${ }^{76}$

Besides the health aspects, sensory quality is often cited as being an important aspect motivating consumers to purchase organic foods. ${ }^{64,65}$ Despite this, there are few studies that compare the sensory quality of organically and conventionally grown carrots under comparable conditions. Haglund et al. ${ }^{77}$ found higher bitter taste $(+19 \%)$ in organic carrots $(2.5)$ in comparison with conventional carrots (2.1, mean of two years and three varieties). In one of the two years, organic carrots also had a $6 \%$ lower score for sweet taste (6.2) compared with conventional carrots (6.6) and a more pronounced aftertaste.

\section{Fertilisation}

Among the factors that explain the difference between organic and conventional farming, fertilisation regime seems to have the highest impact.

The use of animal manure fertilisation introduces a possible risk of microbial contamination in organic as well as conventional farming systems. Contamination by organisms such as Escherichia coli 0157:H7 and Listeria monocytogenes is a potential risk with animal manure fertilisation, as exemplified by lettuce plants in organic farming systems. ${ }^{78,79}$

Microbial contamination has been studied in carrots on the market. ${ }^{80}$ Carrots can be exposed to preharvest contamination with e.g. E. coli $(0157: \mathrm{H} 7)$ by manure or irrigation water. ${ }^{40}$ Also, this pathogen can be present in manure that has been exposed to a composting procedure, and the pathogen can survive for several months in soil. ${ }^{40}$ High temperatures during composting and duration of the composting period are important factors in control of the pathogen. In any case, manure as well as irrigation water should be free of potential pathogens before use. This is important, since carrots are often eaten with the peel intact in raw conditions. For processed carrots, e.g. dried carrot slices, citric acid has been used in combination with moderate heat treatment to eliminate Salmonella. ${ }^{81}$

Nitrate accumulation in vegetables has been the cause of some concern, especially for vegetables used as raw material for baby food. Nevertheless, nitrate accumulation in carrots seems to be less of a safety problem, as carrots fertilised with nitrogen levels up to $150 \mathrm{~kg} \mathrm{~N} \mathrm{ha}^{-1}$ had nitrate levels below the threshold value for baby food ( $250 \mathrm{mg} \mathrm{NO}_{3} \mathrm{~kg}^{-1} \mathrm{FW}$ ). ${ }^{82,83}$ Increasing the nitrogen fertilisation from 60 to $240 \mathrm{~kg} \mathrm{~N} \mathrm{ha}^{-1}$ increased the nitrate content in carrots from 54 to $65 \mathrm{mg} \mathrm{NO}_{3} \mathrm{~kg}^{-1} \mathrm{FW}(+20 \%){ }^{41}$ However, undesirable accumulation of nitrate in carrots seems to occur only in rare situations with high amounts of available nitrogen prior to harvest. ${ }^{69}$ In general, levels of fertilisers, the 
source and timing of fertilisation, conditions for mineralisation, water supply, species and variety are important factors that influence nitrate accumulation in vegetables. ${ }^{69,84}$ Organic carrots showed $46 \%$ reduction in nitrite in comparison with conventional carrots when results from ten conventional and ten organic farms were compared. ${ }^{37}$ A general tendency of lower nitrate level in organically grown vegetables compared with conventional crops can be due to restricted nitrogen supply. ${ }^{85}$

Farming systems with low nitrogen input showed increased bitter flavour $(+16 \%)$ and green flavour $(+12 \%)$ in comparison with conventional and different organic systems with higher levels of nitrogen. ${ }^{32}$ Reduced nitrogen fertilisation may affect nutrient and health aspects of fresh carrots in a positive $17,70,85-87$ or negative ${ }^{41,43,88}$ manner. Sørensen ${ }^{41}$ reported that $\beta$-carotene content was reduced by $12 \%$ with a reduction in nitrogen fertilisation from 240 to $60 \mathrm{~kg} \mathrm{~N} \mathrm{ha}^{-1}$. This could be in accordance with the finding that the biosynthesis of carotene is a nitrogendemanding process. ${ }^{89}$ A similar retarding effect on carotene production in carrots is also seen with a shortage of other elements such as molybdenum, selenium and zinc in fertilisation studies of carrots. $^{29}$

In an experiment where organic carrots were given different levels of green manure fertilisation corresponding to 0,80 and $154 \mathrm{~kg} \mathrm{~N} \mathrm{ha}^{-1}$, DM increased by $2-6 \%$ with decreasing nitrogen levels, depending on year and climatic conditions. ${ }^{43}$ There were no differences in content of sugars, calcium, magnesium or potassium in these studies. However, decreasing the level of nitrogen from 240 to $60 \mathrm{~kg} \mathrm{~N} \mathrm{ha}^{-1}$ reduced the content of $\beta$-carotene by 8 and $11 \%$ and increased the content of ascorbic acid by 9 and $14 \%$ in carrots in two different years respectively. ${ }^{43}$

In general, limitation on the use of nitrogen fertilisers in organic farming systems compared with conventional systems seems to be the reason for higher content of nutrients, sugars and essential amino acids ${ }^{17,70,85-87}$ and phenolic compounds and falcarinol $41,50,69,90$ in organically grown carrots. A reduction in nitrogen from 240 to $60 \mathrm{~kg} \mathrm{~N} \mathrm{ha}^{-1}$ on a sandy loam soil increased the content of manganese by $3 \%$, magnesium by $8 \%$, calcium by $9 \%$ and sucrose by $3 \% .{ }^{41}$ The higher concentration of these constituents can partly be explained by an increase in DM content occurring at reduced nitrogen fertilisation levels. ${ }^{41,43}$ Typically, the DM increase for carrot roots was $1 \%$ by reducing the nitrogen fertilisation from 120 to $60 \mathrm{~kg} \mathrm{~N} \mathrm{ha}^{-1}, 3 \%$ by reducing it from 240 to $120 \mathrm{~kg} \mathrm{~N} \mathrm{ha}^{-1,41}$ and $2-6 \%$, depending on the year, by reducing it from 200 to $25 \mathrm{~kg} \mathrm{~N} \mathrm{ha}^{-1} .^{43}$ It appears that the nitrogen effect (time, amount and availability) of the farming system affects the DM content and thereby indirectly affects the concentration of compounds. ${ }^{91,92}$

In a pot experiment reported by Schaller and Schnitzler, ${ }^{42}$ a decrease in nitrogen supply (from 2.4 to $0.3 \mathrm{~g} \mathrm{~N}$ per pot) increased terpinolene $(+22 \%), \beta$-caryophyllene $(+54 \%), \alpha$-phellandrene and $\beta$-pinene (both $+100 \%)$, sucrose $(+14 \%)$ and malic acid $(+48 \%)$. On the other hand, the same reduction in nitrogen supply decreased nitrate $(-458 \%)$, glucose $(-20 \%)$, fructose $(-57 \%)$ and sucrose $(-63 \%)$. Thus farming with reduced levels of nitrogen can increase carrot aroma and decrease sugar content and sweet taste.

Among other macronutrients, potassium seems to have no influence on quality characteristics such as sugar content or carotene $^{93}$ or sensory quality. ${ }^{30}$ On the other hand, increasing potassium nutrition may affect the shelf life of carrots positively by decreasing postharvest moisture loss. ${ }^{94}$

\section{Pest attack}

In addition to yield losses, attacks by plant pathogens and insect pests can influence the safety of carrots by stimulating the production of secondary compounds either by the plant (phytoalexins) or by fungi (mycotoxins). Phytoalexins may be either healthy or unhealthy to humans, and not all compounds have been studied with respect to safety. Mycotoxins are either more or less toxic to humans. ${ }^{95}$

Even though some mycotoxin-producing fungi are able to grow on carrot tissue in the laboratory, ${ }^{96,97}$ there are no reports on mycotoxins in carrots on the market. The studies of effects of farming system on mycotoxin-producing plant pathogens show contradictory results and do not clearly favour organic or conventional farming. ${ }^{98,99}$

The most studied carrot phytoalexins are dihydroisocoumarins (mainly 6-methoxymellein), which are induced after exposure to ethylene, UV radiation, mechanical injury or temperature stress under pre- and postharvest conditions. ${ }^{21,22}$ These compounds are known to have antibiotic properties and are also produced by carrots after being infected by several plant-pathogenic fungi, e.g. Botrytis cinerea, Ceratocystis fimbriata, Ceratocystis ulmi, Helminthosporium carbonum, Fusarium oxysporum and Fusarium lycopersici. $^{22,100,101}$

Attack from insect pests may stimulate the production of certain secondary compounds in carrots as a protection mechanism. Longterm stress from insect attack by Trioza apicalis had an enhancing effect on antioxidant capacity $(+175 \%)$, content of tocopherol $(+208 \%)$, bitter compounds such as falcarindiol $(+300 \%)$ and 6methoxymellein $(+3495 \%)$ as well as terpenes $(+90 \%)$. These changes resulted in increased sensory scores for bitter taste $(+98 \%)$, chemical flavour $(+171 \%)$, terpene flavour $(+116 \%)$ and toughness $(+121 \%) .{ }^{44}$ Attack of T. apicalis decreased total sugar $(-26 \%)$, fructose $(-27 \%)$, glucose $(-50 \%)$ and sensory variables sweet taste $(-195 \%)$, colour hue $(-45 \%)$, crispiness $(-35 \%)$ and juiciness $(-43 \%){ }^{44}$ However, these dramatic results were obtained in an extreme situation with $86 \%$ reduction in yield. The observation of increased bitter taste that sometimes occurs in organic cultivation systems ${ }^{77}$ may partly be explained by an increase in psyllid attack and production of bitter compounds such as 6-methoxymellein and falcarindiol. ${ }^{44}$

\section{Pest control method}

In addition to fertilisation regime, the main differences between organic and conventional farming systems are the pest control methods used. Pesticide residues have become a special concern not only as a threat to humans but also in terms of consumer anxiety. In a German study of pesticide residues in carrots, $93 \%$ of conventionally grown carrots were contaminated as opposed to $32 \%$ of organically grown carrots during the period 2002-2006. ${ }^{46}$ According to the follow-up 2011 report, pesticide residues (clomazon and pendimethalin) were found in only $7.1 \%$ of investigated organic carrot samples. ${ }^{102}$ The negative pesticide effect is an important factor favouring organic over conventional carrots. ${ }^{46}$ In contrast to conventional pesticide treatment, organic systems mainly use insect nets to protect against insect pests, crop rotation to protect against fungal diseases, and mechanical and thermal treatment to protect against weeds. Insect nets can influence sensory or health-related quality aspects by increasing temperature and humidity and reducing light intensity during carrot growth. In a study by Rashed ${ }^{50}$ the content of falcarinol was reduced by insect nets compared with conventional crop protection by pesticide use. 


\section{POSTHARVEST FACTORS INFLUENCING QUALITY ASPECTS}

The quality of carrots at harvest is not an end-point quality but could be affected by certain factors occurring in the period between harvest and consumption (Table 2). After harvest, carrots are normally kept for a period in cold storage before being transported to grocery stores. Following a certain period on the shelf (chilled or at room temperature), carrots are stored by consumers in the refrigerator before consumption. Temperature, atmosphere and humidity during storage and distribution are important factors that affect nutritional and health aspects as well as shelf life. In the following subsections the postharvest factor contributions to differences in content of chemical compounds and sensory quality are discussed.

\section{Mechanical stress}

During the harvesting process, carrots are exposed to stress. Mechanical stress from traditional machine harvesting (ASA-LIFT, Dianalund, Denmark) did not cause changes in sensory aspect by harvesting with shock absorbers. ${ }^{103}$ However, exposure of newly harvested carrots to strong mechanical stress ('shipping tester'EMB 049, Nofima, Ås, Norway) had clear negative effects on sensory quality, expressed by $34 \%$ reduction in sweet taste (from 5.03 to 3.75 ), $45 \%$ increase in ethanol flavour (from 1.24 to 2.27 ) and $27 \%$ increase in sickeningly sweet taste (from 1.40 to 1.91 ). ${ }^{103}$ These results matched the occurrence of ethanol (not detected, ND, vs $\left.226 \mathrm{mg} \mathrm{kg}^{-1}\right)$, a small reduction in sucrose content (-4\%) as well as a 14-fold increase in the bitter compound 6-methoxymellein $(+1395 \%) .^{103}$

\section{Temperature}

Exposure to high postharvest temperatures affects the shelf life aspects as well as nutritional, health and sensory aspects of fresh and minimally processed carrots. Increased respiration and aging processes of carrots are related to effects of postharvest factors such as mechanical stress, low humidity and unfavourable atmosphere in packaging. ${ }^{35,105,107}$ In long-term cold storage at $0{ }^{\circ} \mathrm{C}$ the respiration rate is minimal ${ }^{116}$ and pathogen growth is restricted. ${ }^{117}$ High retail temperature $\left(20\right.$ vs $\left.2{ }^{\circ} \mathrm{C}\right)$ increased the negatively associated characteristics bitter taste $(+13 \%)$, aftertaste $(+11 \%)$, sickeningly sweet taste $(+48 \%)$, terpene flavour $(+15 \%)$ and earthy flavour $(+22 \%)$ as well as causing a reduction in acidic taste $(-20 \%)$ of carrots. ${ }^{105}$ The storage of carrots seems to have inconsistent effects on the content of $\beta$-carotene, depending on temperature levels. At low temperature $\left(4{ }^{\circ} \mathrm{C}\right), \beta$-carotene increased by $8-23 \%$ after 4 weeks of storage compared with the level at harvest. ${ }^{106}$ In a study by Negi and Roy, ${ }^{104} 8$ days of storage at different temperatures reduced the $\beta$-carotene content by $46 \%$ $\left(7.5-8.5^{\circ} \mathrm{C}\right), 51 \%\left(17-21^{\circ} \mathrm{C}\right)$ and $70 \%\left(22-37.5^{\circ} \mathrm{C}\right)$ compared with initial levels. ${ }^{104}$ Similarly, ascorbic acid was reduced by $38 \%$ after 8 days of storage at $7.5-8.5^{\circ} \mathrm{C}$ and by $70 \%$ at $22-37.5^{\circ} \mathrm{C} .{ }^{104}$ Total sugars decreased by $4 \%$ after 10 days of storage at $20^{\circ} \mathrm{C}$ compared with $2{ }^{\circ} \mathrm{C} .{ }^{105}$

\section{Humidity}

Because the peel of carrots is very thin and highly waterpermeable, low air humidity reduces shelf life by increasing shrivelling of carrots. ${ }^{109,110}$ Storage of carrots at $98-100 \%$ relative humidity combined with low temperature is required to preserve their content of health-related compounds, sensory quality and shelf life. ${ }^{118,119}$ This is mainly achieved by bulk storage in boxes with a perforated plastic lining to obtain humidity saturation. To maintain the necessary humidity during the distribution chain, carrots are generally packed in ventilated polyethylene bags. ${ }^{120}$

Storage of unpacked carrots compared with carrots packed in ventilated PE bags showed reduction in $\beta$-carotene $(-42$ and $-45 \%)$ and ascorbic acid ( -44 and $-114 \%$ for ambient and cool storage respectively). ${ }^{104}$ In a study by Soria et al., ${ }^{108}$ dehydration of carrots caused a reduction in $\beta$-carotene $(-35 \%)$, fructose $(-67$ to $-81 \%)$ and glucose ( -54 to $-85 \%)$ and an increase in sucrose $(+50$ to $+53 \%)$. However, these results are influenced by the variety factor. The results indicate that unpacked carrots or carrots packed in paper bags or other materials that do not provide high humidity are exposed to rapid losses of nutrients during marketing.

\section{Atmospheric gases and ethylene}

Storage in controlled or modified atmosphere positively increases the shelf life of many plant products ${ }^{121}$ by slowing down respiration. Respiration rate is influenced by gas concentration and temperature, and the rate has been modelled for shredded carrots. ${ }^{116}$ Nevertheless, storage of carrots at low $\mathrm{O}_{2}$ status in modified atmosphere (7 vs $21 \% \mathrm{O}_{2}$ ) in different package types seems to affect the sensory aspect in a negative manner by increasing the anaerobic respiration and ethanol content (ND to $576 \mathrm{mg}$ ethanol $\left.\mathrm{kg}^{-1} \mathrm{FW}\right) .{ }^{105}$ The anaerobic respiration clearly increased the sensory scores for sickeningly sweet taste (from 1.98 to $3.33,+68 \%$ ) and ethanol flavour (from 1.35 to $3.10,+130 \%$ ) of the carrots after 10 days of low $\mathrm{O}_{2}$ concentration. ${ }^{105}$ Increasing the temperature from 2 to $20{ }^{\circ} \mathrm{C}$ magnified the effect of low $\mathrm{O}_{2}$ level and increased the sickeningly sweet taste by $49 \%$ and the ethanol flavour by $102 \%$. The negative effects of low $-\mathrm{O}_{2}$ atmosphere are confirmed by other studies. ${ }^{114,115}$ Thus modified or controlled atmosphere should be avoided or used with discretion for fresh or minimally processed carrots, and the $\mathrm{O}_{2}$ permeability of packages should be sufficient to avoid negative impact on the sensory aspect. $^{105}$

Ethylene stimulates the production of the bitter compound 6-methoxymellein in carrots and thus affects the sensory aspect negatively. ${ }^{35,111,112}$ 6-Methoxymellein is normally present at minor levels in carrots stored in air, but upon storage in ethylene-enriched air $\left(1 \mu \mathrm{L} \mathrm{L}^{-1}\right)$ the level increased to 5, 7 and $13 \mathrm{mg} \mathrm{kg}^{-1} \mathrm{FW}$ after 1,2 and 3 weeks respectively. ${ }^{111}$ The level after 3 weeks of storage corresponded to a 20 -fold increase $(+2580 \%)$ compared with the level in carrots stored in air $\left(0.5 \mathrm{mg} \mathrm{kg}^{-1} \mathrm{FW}\right)$. The sensory score for bitter taste increased by $30 \%$ under storage in ethylene-enriched air $\left(1 \mu \mathrm{LL}^{-1}\right)$ compared with storage in ethylene-free air (5.1 vs 4.2) after 2 weeks. ${ }^{111}$ The ethylene treatment also caused a reduction in total sugars $(-30 \%)$ and an increase in terpene flavour $(+17 \%)$ and aftertaste $(+7 \%) .{ }^{11}$ Storage of carrots with apples and other ethylene-producing fruits and vegetables induces a bitter taste in carrots. ${ }^{112,113}$ This should be avoided during transport, at retail stores and in consumers' refrigerators.

\section{PROCESSING FACTORS INFLUENCING QUALITY ASPECTS}

Processing of carrots positively affects the preservation of the product, prolongs shelf life and provides ready-to-use products for the consumer. However, processing also affects several quality aspects (Table 3 ). Therefore processing treatments 


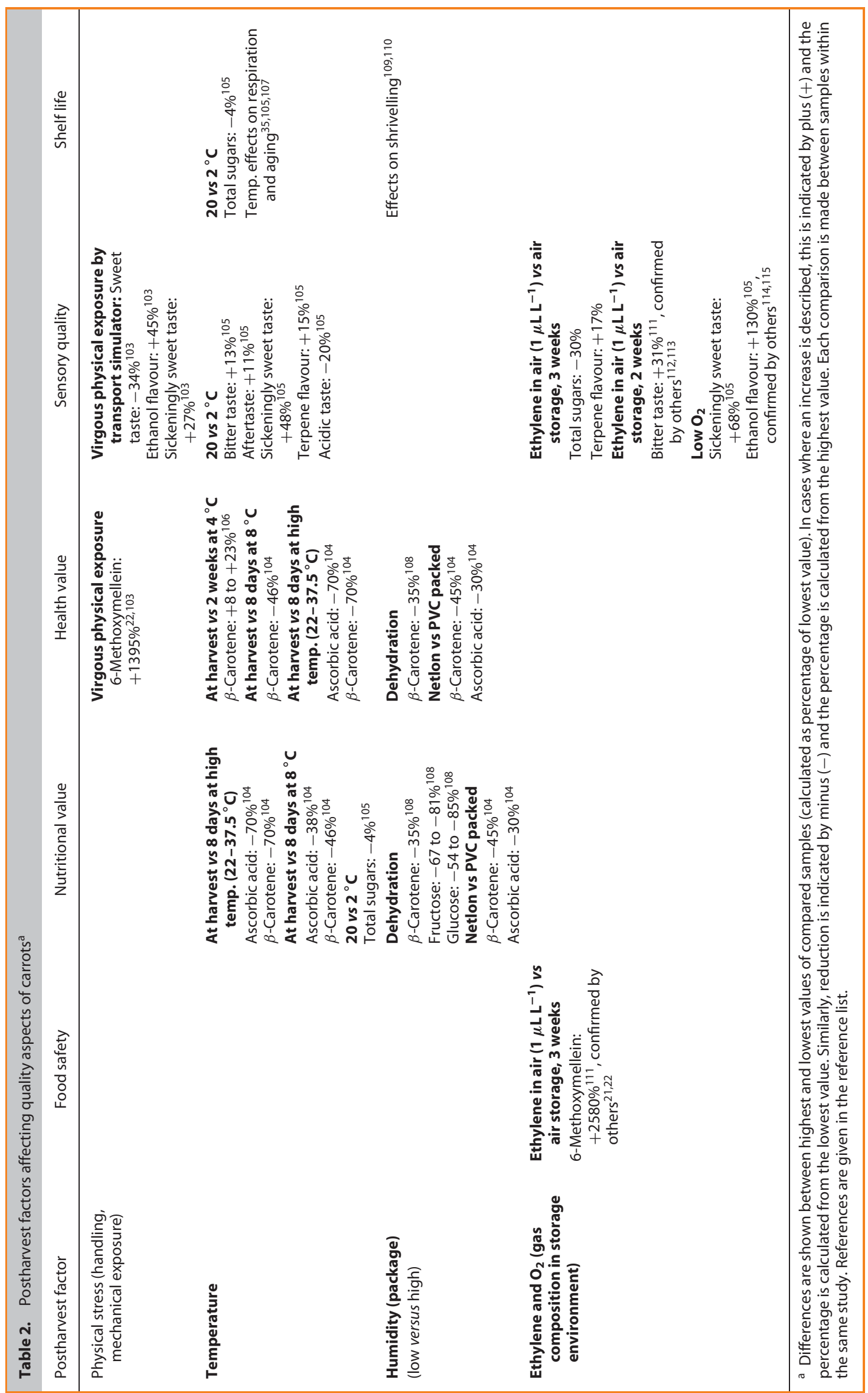




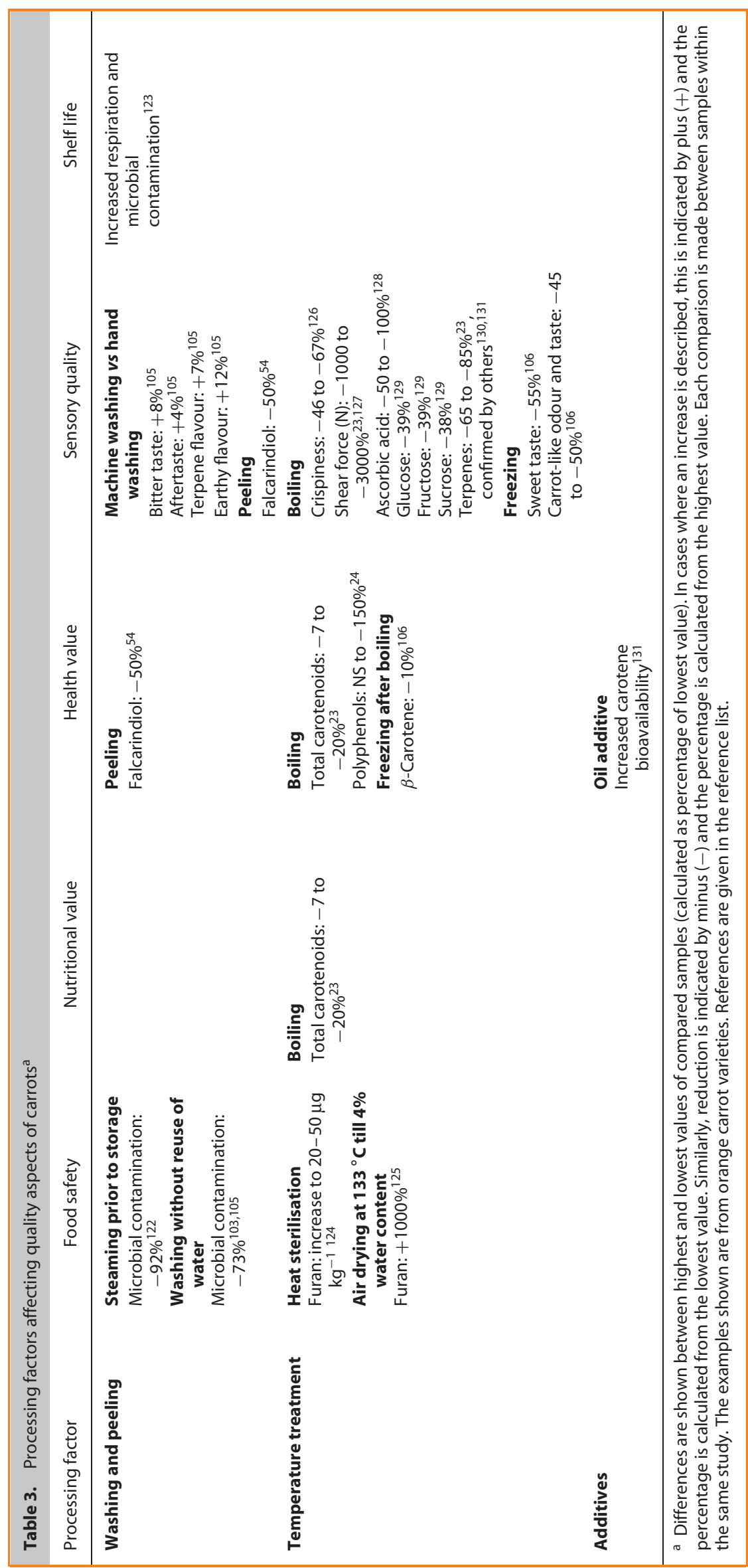


should be as careful or mild as possible in order to preserve nutritional and health aspects and safety. In the following subsections the processing factor contributions to differences in content of chemical compounds and sensory quality are discussed.

\section{Washing and peeling of raw material}

Washing is the first step in the processing of carrots. Traditional machine washing of carrots has been shown to increase the risk of infection by plant pathogens. In comparison with hand washing, washing by machine increased sensory scores for bitter taste $(+8 \%)$, aftertaste $(+4 \%)$ and terpene flavour $(+7 \%)$ as well as earthy flavour $(+12 \%){ }^{105}$ The dropping of roots on assembly lines causes stress, and the higher the drop, the higher the stress. ${ }^{105}$ The type of machinery and the use of shock absorbers may reduce the stress level during washing and grading.

Quantitative analysis of the intermediate products in industrial carrot processing revealed that removing the peel as well as green parts successfully decreased the concentration of bitter-tasting falcarindiol in carrot puree by $50 \% .{ }^{54}$ Nevertheless, peeling after washing of carrots may increase respiration rates and microbial contamination as well as affecting $\mathrm{pH}$ level ${ }^{123}$ and thereby influence safety and shelf life aspects. Micrographs of the peeled surfaces confirmed that abrasion peeling inflicted the greatest damage. ${ }^{123}$ Washing and peeling should be done as close to processing as possible to avoid development of off-flavours by the carrots.

Afek et al. ${ }^{122}$ showed that carrot decay caused by pathogens can be reduced by $92 \%$ (from 65 to $5 \%$ damage) by steaming carrots for $3 \mathrm{~s}$ prior to storage. A reduction in pathogen infection and thereby a prolongation of shelf life are also seen by washing without reuse of water (73\% pathogen reduction). ${ }^{103,105}$

The use of additives in the water used for washing of organic products is regulated and very limited compared with that of conventional production. There are no regulations about the reuse of water on organically grown carrots. ${ }^{132} \mathrm{New}$ possibilities such as the use of ozone instead of citric acid could be an alternative for reducing water consumption in the washing of organic vegetables. ${ }^{132}$

\section{Temperature treatment (boiling or freezing)}

One of the most common processing steps for preservation is heat treatment. Boiling highly affects the sensory aspects by reducing crispiness and making the texture softer ${ }^{126}$ and reducing shear force $(\mathrm{N})(-1000$ to $-3000 \%))^{23,127}$ Boiling for $5 \mathrm{~min}$ reduced the sensory score for crispiness by $44-67 \%$ (from 8.4 for fresh carrots to between 2.8 and 4.7 for boiled carrots, depending on the cultivar). ${ }^{126}$ A $10-30$-fold reduction in shear pressure was measured after cooking of fresh or frozen raw material of carrots. ${ }^{23,127}$ Further, heat treatment affects the safety aspect by reducing the risk of microbial contamination. Pre-cut heat treatment $\left(100{ }^{\circ} \mathrm{C}, 45 \mathrm{~s}\right)$ decreased the microbial activity and also reduced the respiratory activity of shredded carrots and extended the shelf life more than chlorinated water treatment $\left(200 \mu \mathrm{g} \mathrm{mL}{ }^{-1}\right.$ active chlorine, $\left.1 \mathrm{~min}, 5{ }^{\circ} \mathrm{C}\right) .{ }^{133} \mathrm{In}$ addition to traditional heat treatment (boiling), high-pressure homogenisation processing is a promising technology to achieve pathogen decontamination. This method is commonly used in the processing of juice. ${ }^{134}$

The digestibility and bioavailability of different nutrients in carrots may vary with the mode and degree of preparation and processing. As an example, absorption of carotenoids from raw vegetables can be fairly low (18\% from mixed vegetables), while heating can give up to a 6-fold increase in uptake. ${ }^{135,136}$

Despite its positive effects on the safety aspect and carotene bioavailability, thermal treatment during cooking may have a negative impact on nutritional and health aspects through formation and degradation of health-related compounds. Depending on the cultivar, carotenoid levels were reduced by $11-20 \%$ for fresh cooked carrots and $7-20 \%$ for frozen cooked carrots. ${ }^{23}$ At the same time, aroma compounds (terpenes) were reduced by $70-85 \%$ for fresh cooked carrots and $65-80 \%$ for frozen cooked carrots. Boiling for 7 min decreased the contents of glucose, fructose and sucrose by 39,39 and $38 \%$ respectively. ${ }^{129}$ Boiling can also reduce the ascorbic acid content by $50-100 \% .^{128}$

Frozen storage of cooked carrots reduced total carotenes by $10 \%$ after 4 weeks of storage at $-18{ }^{\circ} \mathrm{C}$ and by $6 \%$ after 8 weeks of storage at $-25^{\circ} \mathrm{C} .{ }^{106}$ Immediately after freezing of fresh carrots a $45 \%$ decrease in sensory score for sweet taste (6.6 vs 3.6), a $37 \%$ decrease in carrot-like odour (6.4 vs 3.9) and a $44 \%$ decrease in carrot-like taste (6.8 vs 3.8) were observed. ${ }^{106}$ After 1 year of frozen storage of blanched carrots (at -18 to $-28{ }^{\circ} \mathrm{C}$ ), higher scores for grassy flavour and firm texture were observed in comparison with fresh blanched carrots.

The carcinogenic compound furan may be formed during heat treatment of carrots via thermal oxidation of carotenoids and sugars, particularly during sterilisation of sealed containers. ${ }^{137}$ This contaminant is very reactive and increases the risk of cancer by binding to DNA and forming the highly carcinogenic metabolite cis-2-butene-1,4-dial. ${ }^{138-140}$ Furan may accumulate by heat treatment of canned carrot products to levels between 20 and $50 \mu \mathrm{g} \mathrm{kg}^{-1} .^{124}$ In canned vegetables, furan is trapped in the product during the heat sterilisation process. ${ }^{141}$ The accumulation of furan can be reduced by alternative sterilisation techniques such as ohmic heating, which allows very rapid temperature increase followed by rapid cooling in the complete volume. ${ }^{142}$ This limits heat-generating reactions. Smashing and cooking operations may also increase the level of other neoformed compounds such as carboxymethyllysine and furosine, which have been used as markers for product age and heat exposure. ${ }^{143}$ Front face fluorescence can be used as a tool to monitor the effect of heat processing on neoformed contaminants in carrot products. ${ }^{143}$

Furan may also increase during air drying of carrot slices at temperatures from 93 to $133{ }^{\circ} \mathrm{C}^{125}$ Furan formation started at $<40 \%$ water content and thereafter increased exponentially with drying temperature. By $133^{\circ} \mathrm{C}$, carrot slices at $5 \%$ moisture content contained $275 \mu \mathrm{g} \mathrm{kg}^{-1}$ furan, which was 10 times higher than that found in fresh carrot slices. ${ }^{125}$

\section{Additives}

More than 300 additives are registered for conventional products while only 47 are available for organic products (EC Regulation No. 1333/2008). Addition of other food products during processing of food to create mixed products is debatable. Reduction in selected additives could be of importance for persons who show allergic reactions to specific additives. However, addition of oils can improve the quality of carrot products, since the occurrence of dietary lipids is believed to be important for carotenoid bioavailability in humans. ${ }^{131,135}$ Adding $10 \%$ of olive oil to boiled carrots increased the uptake of carotenes in by $80 \%$. This improvement could be utilised in the development of processed carrot products with specific health profiles. 


\section{DISCUSSION AND CONCLUSION}

The genetic factor, which can be controlled by the farmer through selection of variety, clearly has the highest impact on most of the quality variables. When extreme varieties are compared, 7-11-fold differences can be found in phenolics (1127\%), $\beta$-carotene (900\%) and terpenes (730\%) as well as 1-4-fold differences in falcarindiol (430\%), magnesium (370\%), iron (294\%), bitter taste (209\%) and sweet taste $(160 \%)$ and up to $60 \%$ difference in DM (Fig. 1A).

Climate factors may affect terpene content 20-fold between extremes (1982\%). Considerable variation can also be seen for total sugars ( $82 \%), \beta$-carotene ( $40 \%)$, phenolics (28\%), sweet taste (35\%), bitter taste (30\%) and DM (29\%) when comparing carrots grown in different climates, locations or years (Fig. 1B). Thus the quality that is laid down by a particular variety or cultivation practice can to large extent be changed in unexpected directions by climate factors.

Choice of organic compared with conventional farming may to some extent change the quality of carrots by increasing the content of minerals such as magnesium $(+70 \%)$ and iron $(+10 \%)$ as well as decreasing nitrite content $(-46 \%)$ and slightly decreasing ascorbic acid content (-3\%) (Fig. 1C). Low nitrogen fertilisation of carrots, which is part of the organic cultivation concept, may increase the content of terpenes $(+100 \%)$, magnesium $(+8 \%)$ and DM $(+6 \%)$ as well as reduce the content of nitrate $(-20 \%)$ and $\beta$-carotene (-12\%) (Fig. 1D).

Another factor related to organic cultivation is the ban on pesticides, which reduces the risk of pesticide residues but increases the risk of damage by pest attack. In addition to yield loss and product damage, insect pests may reduce sensory quality by raising the content of the bitter compounds falcarindiol $(+300 \%)$ and 6-methoxymellein $(+3495 \%)$ as well as increasing bitter taste $(+98 \%)$ and reducing sweet taste $(-195 \%)$ and sugar content $(-26 \%)$ (not shown in figure).

Quality obtained at harvest may be degraded by elevated temperatures during storage and retail (Fig. 1E). High versus low retail temperature (room temperature versus cold storage) reduces shelf life but also affects nutritional and health aspects of carrots by decreasing the content of $\beta$-carotene $(-70 \%)$, total sugars $(-4 \%)$ and ascorbic acid $(-70 \%)$. At the same time, high retail temperature represents a potential risk for reduction in sensory quality by increasing bitter taste $(+13 \%)$ and sickeningly sweet taste $(+48 \%)$. Postharvest mechanical stress due to low $\mathrm{O}_{2}$ level or ethylene exposure may additionally reduce sensory quality by generating sickeningly sweet taste or bitter taste respectively (not shown in figure).

Heat processing by boiling affects texture by reducing shear force, crispiness and DM. At the same time, boiling affects nutritional and health aspects by degrading phenolics $(-150 \%)$, ascorbic acid $(-100 \%)$, terpenes $(-85 \%)$, total carotenes $(-20 \%)$ and sucrose $(-38 \%)$ (Fig. 1F). Heat treatment of sealed containers also affects the safety aspect by increasing the content of the unwanted compound furan up to 10 -fold. This can be minimised by the use of ohmic heating in the sterilisation process of closed containers. Bioavailability of carotenes in the body may increase up to 6 -fold by boiling and by $80 \%$ with oil addition.

From the perspective of safety the most important factors are the control of human pathogens (e.g. E. coli) in fertilisers and irrigation

Effect of important factors on quality of carrots

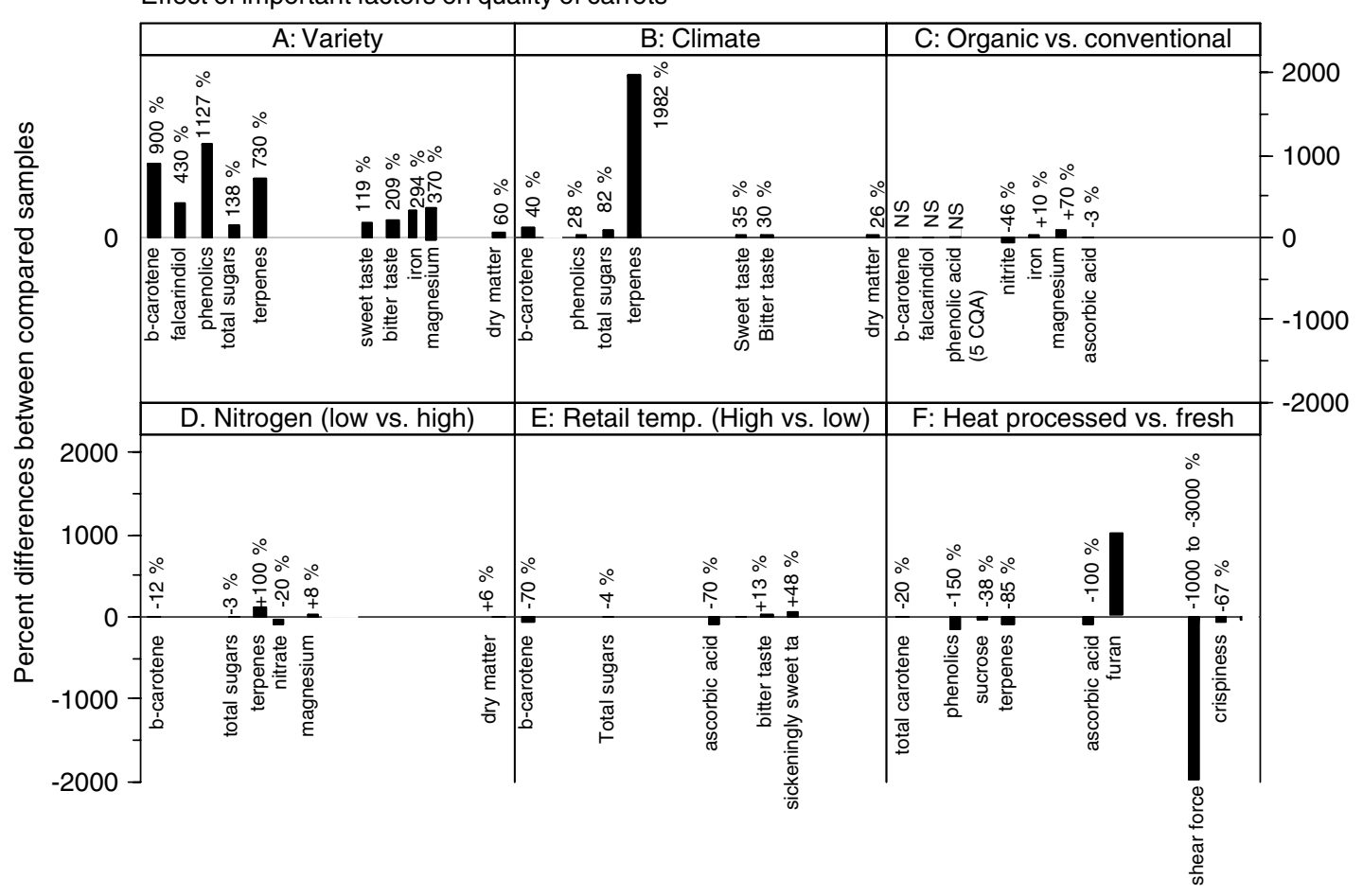

Figure 1. Illustration of reported maximum variation between high and low levels of important response variables describing quality of carrots. Examples are given for variation between extremes within varieties $(A)^{7-13}$ and climate-related factors $(B)^{7,14,15,33}$ as well as organic versus conventional farming system (C), ${ }^{15-17,38,39}$ low versus high nitrogen fertilisation (D), ${ }^{38,41-43}$ high versus low retail temperature $(E)^{104,105}$ and heat-processed versus fresh (F). ${ }^{23,24,124,125,127-129}$ Comparisons are made between samples within the same study. In cases where an increase is described, this is indicated by positive bar $(+)$ and the percentage is calculated from the lowest value. Similarly, reduction is indicated by negative bar $(-)$ and the percentage is calculated from the highest value. NS = not significantly affected by the tested factors. 
water and the control of pesticide residues in products. Also, the accumulation of radioactive compounds as well as cadmium and other heavy metals from soil represents a preharvest hazard in some areas. To some extent, heavy metal accumulation can be controlled by adjusting the $\mathrm{pH}$ level in soil. To ensure consumer trust, these safety factors are of high importance.

Owing to the strong genetic effect on several important quality parameters, there is potential to plan and ensure a certain quality at harvest. However, these genetically determined characteristics may be influenced in unpredictable directions by climate-related factors. The cultivation method seems to have a minor influence on quality in comparison with genetic and climate-related factors. During storage the initial quality may be influenced by further changes. A low retail temperature and absence of ethylene and sufficient $\mathrm{O}_{2}$ concentration in the atmosphere and packaging are important to avoid quality reduction. For heat-processed carrot products the heating method should be adjusted to avoid formation of the carcinogenic compound furan.

\section{ACKNOWLEDGEMENTS}

The authors wish to acknowledge the funding bodies of the Core Organic network in their respective countries. We also acknowledge senior scientist Leif Sundheim and senior statistics adviser Torfinn Torp (Bioforsk Plant Health) and research scientist Ingunn Vaagen (Bioforsk Arable Crops) for valuable comments on the manuscript.

\section{REFERENCES}

1 Atkin JD, Bitter flavor in carrots. II. Progress report on field and storage experiments. Report No. 774, Cornell University New York State Agricultural Experiment Station, Geneva, NY (1956).

2 Sondheimer E, Phillips WF and Atkin JD, Bitter flavor in carrots. I. A tentative spectrophotometric method for the estimation of bitterness. Food Res 20:659-665 (1955).

3 Simon PW, Peterson CE and Lindsay RC, Genetic and environmental influences on carrot flavor. J Am Soc Hort Sci 105:416-420 (1980).

4 Peto R, Doll R, Buckley JD and Sporn MB, Can dietary beta-carotene materially reduce human cancer rates? Nature 290:201-208 (1981).

5 Hansen SL, Purup S and Christensen LP, Bioactivity of falcarinol and the influence of processing and storage on its content in carrots (Daucus carota L.). J Sci Food Agric 83:1010-1017 (2003).

6 Purup S, Larsen E and Christensen LP, Differential effects of falcarinol and related aliphatic $\mathrm{C}_{17}$-polyacetylenes on intenstinal cell proliferation. J Agric Food Chem 57:8290-8297 (2009).

7 Simon PW and Peterson CE, Genetic and environmental components of carrot culinary and nutritive value. Acta Hort 93:271 - 278 (1979).

8 Alasalvar C, Grigor JM, Zhang D, Quantick PC and Shahidi F, Comparison of volatiles, phenolics, sugars, antioxidant vitamins, and sensory quality of different colored carrot varieties. J Agric Food Chem 49:1410-1416 (2001).

9 Bajaj KL, Kaur G and Sukhija BS, Chemical composition and some plant characteristics in relation to quality of some promising cultivars of carrot (Daucus carota L.). Qual Plant Plant Foods Hum Nutr 30:97-107 (1980).

10 Metzger BT, Barnes DM and Reed JD, Purple carrot (Daucus carota L.) polyacetylenes decrease lipopolysaccharide-induced expression of inflammatory proteins in macrophage and endothelial cells. $J$ Agric Food Chem 56:3554-3560 (2008).

11 Heatherbell DA and Wrolstad RE, Carrot volatiles. II. Influence of variety, maturity and storage. J Food Sci 36:225-227 (1971).

12 Kreutzmann S, Thybo AK, Edelenbos M and Christensen LP, The role of volatile compounds on aroma and flavour perception in coloured raw carrot genotypes. Int J Food Sci Technol 43:1619-1627 (2008).

13 Da Silva EA, Vieira MA, Vieira EA, Amboni RDMC, Amante ER and Teiexeira E, Chemical, physical and sensory parameters of different carrot varieties (Daucus carota L.). J Food Process Eng 30:746-756 (2007).
14 Rosenfeld HJ, Samuelsen RT and Lea P, Relationship between physical and chemical characteristics of carrots grown at northern latitudes. J Hort Sci Biotechnol 73:265-273 (1998).

15 Soltoft M, Nielsen J, Lauren KH, Husted S, Halekoh U and Knuthsen $P$, Effects of organic and conventional growth systems on the content of flavonoids in onions and phenolic acids in carrots and potatoes. J Agric Food Chem 58:10323-10329 (2010).

16 Lima GPP, da Rocha SA, Takaki M, Ramos PRR and Ono EO, Comparison of polyamine, phenol and flavonoid contents in plants grown under conventional and organic methods. Int J Food Sci Technol 43:1838-1843 (2008).

17 Worthington $\mathrm{V}$, Nutritional quality of organic versus conventional fruits, vegetables, and grains. J Altern Compl Med 7:161-173 (2001).

18 Pandey J and Pandey U, Accumulation of heavy metals in dietary vegetables and cultivated soil horizon in organic farming system in relation to atmospheric deposition in a seasonally dry tropical region of India. Environ Monit Assess 148:61 - 74 (2009).

19 Cappon CJ, Mercury and selenium content and chemical form in vegetable crops grown on sludge-amended soil. Arch Environ Contam Toxicol 10:673-689 (1981).

20 Guttormsen G, Singh BR and Jeng AS, Cadmium concentration in vegetable crops grown in a sandy soil as affected by $\mathrm{Cd}$ levels in fertilizer and soil-pH. Fertilizer Res 41:27-32 (1995).

21 Kuc J and Currier W, Phytoalexins, plants, and human health. Adv Chem 149:356-368 (1976).

22 Superchi S, Pini D, Salvadori P, Marinelli F, Rainaldi G, Zanelli U, et al., Synthesis and toxicity to mammalian cells of the carrot dihydroisocoumarins. Chem Res Toxicol 6:46-49 (1993).

23 Simon PW and Lindsay RC, Effects of processing upon objective and sensory variables of carrots. J Am Soc Hort Sci 108:928-931 (1983).

24 Faller ALK and Fialho E, The antioxidant capacity and polyphenol content of organic and conventional retail vegetables after domestic cooking. Food Res Int 42:210-215 (2009).

25 Baardseth P, Rosenfeld HJ, Sundt TW, Skrede G, Lea P and Slinde E, Evaluation of carrot varieties for production of deep fried carrot chips - II. Sensory aspects. Food Res Int 28:513-519 (1996).

26 Cappon CJ, Uptake and speciation of mercury and selenium in vegetable crops grown on compost-treated soil. Water Air Soil Pollut 34:353-361 (1987).

27 Zheng RL, Li HF, Jiang RF and Zhang FS, Cadmium accumulation in the edible parts of different cultivars of radish, Raphanus sativus $L$., and carrot, Daucus carota var. sativa, grown in a Cd-contaminated soil. Bull Environ Contam Toxicol 81:75-79 (2008).

28 Ban-Nai T, Muramatsu Y and Yanagisawa K, Transfer of some selected radionuclides ( $\mathrm{Cs}, \mathrm{Sr}, \mathrm{Mn}, \mathrm{Co}, \mathrm{Zn}$ and $\mathrm{Ce}$ ) from soil to root vegetables. J Radioanal Nucl Chem 241:529-531 (1999).

29 Biacs PA, Daood HG and Kadar I, Effect of Mo, Se, Zn, and Cr treatments on the yield, element concentration, and carotenoid content of carrot. J Agric Food Chem 43:589-591 (1995).

30 Seljåsen $\mathrm{R}$, Lea $\mathrm{P}$, Torp $\mathrm{T}$, Riley $\mathrm{H}$, Berentsen $\mathrm{E}$, Thomsen $\mathrm{M}$ and Bengtsson GB. Effects of genotype, soil type, year and fertilisation on sensory and morphological attributes of carrots (Daucus carota L.). J Sci Food Agric 92:1786-1799 (2012).

31 Jansson $\mathrm{G}$ and Öborn I, Cadmium content of Swedish carrots and the influence of soil factors. Acta Agric Scand B 50:49-56 (2000).

32 Paoletti F, Raffo A, Kristensen HL, Thorup-Kristensen K, Ploeger A and Kahl J, Multi-method comparison of carrot quality from a conventional and three organic cropping systems with increasing levels of nutrient recycling. J Sci Food Agric 92:2855-2869 (2012).

33 Rosenfeld HJ, Samuelsen RT and Lea P, The effect of temperature on sensory quality, chemical composition and growth of carrots (Daucus carota L.). I. Constant diurnal temperature. J Hort Sci Biotechnol 73:275-288 (1998).

34 Evers AM, Tuuri H, Hagg M, Plaami S, Hakkinen $U$ and Talvitie $H$, Soil forming and plant density effects on carrot yield and internal quality. Plant Foods Hum Nutr 51:283-294 (1997).

35 Lafuente MT, Cantwell M, Yang SF and Rubatzky V, Isocoumarin content of carrots as influenced by ethylene concentration, storage temperature and stress conditions. Acta Hort 258:523-534 (1989).

36 Simon PW, Peterson CE and Lindsay RC, Genotype, soil, and climate effects on sensory and objective components of carrot flavor. J Am Soc Hort Sci 107:644-648 (1982).

37 Rembialkowska E, The nutritive and sensory quality of carrots and white cabbage from organic and conventional farms, in IFOAM 2000 - The World Grows Organic 2000: Proceedings 13th 
International IFOAM Scientific Conference, Basel, 28-31 August, ed. by Alfoldi T, Lockeretz W and Niggli U. vdf Hochschulverlag AG and der ETH Zürich, Zürich, pp. 297 (2000).

38 Søltoft M, Bysted A, Madsen KH, Mark AB, Bugel SG, Nielsen J, et al., Effects of organic and conventional growth systems on the content of carotenoids in carrot roots, and on intake and plasma status of carotenoids in humans. J Sci Food Agric 91:767-776 (2011).

39 Søltoft M, Eriksen MR, Träger AWB, Nielsen J, Laursen KH, Husted $\mathrm{S}$, et al., Comparison of polyacetylene content in organically and conventionally grown carrots using a fast ultrasonic liquid extraction method. J Agric Food Chem 58:7673-7680 (2010)

40 Islam M, Doyle MP, Pathak SC, Millner P and Jiang X, Survival of Escherichia coli $\mathrm{O} 157: \mathrm{H7}$ in soil and on carrots and onions grown in fields treated with contaminated manure compost or irrigation water. Food Microbiol 22:63-70 (2005).

41 Sorensen JN, Nitrogen effects on vegetable crop production and chemical composition. Proc. Int. Workshop on Ecological Aspects of Vegetable Fertilisation in Integrated Crop Production in the Field, pp. 41-49 (1999).

42 Schaller RG and Schnitzler WH, Nitrogen nutrition and flavour compounds of carrots (Daucus carota L) cultivated in Mitscherlich pots. J Sci Food Agric 80:49-56 (2000).

43 Kaack K, Nielsen M, Christensen LP and Thorup-Kristensen K Nutritionally important chemical constituents and yield of carrot (Daucus carota $\mathrm{L}$.) roots grown organically using ten levels of green manure. Acta Agric Scand B 51:125-136 (2001).

44 Seljåsen R, Vogt G, Olsen E, Lea P, Høgetveit LA, Tajet T, et al., Influence of field attack by carrot psyllid (Trioza apicalis Förster) on sensory quality and content of terpenoids, falcarindiol, 6-methoxymellein and antioxidants of carrots (Daucus carota L.). J Agric Food Chem 61:2831-2838 (2013)

45 Nissinen Al, Lemmetty A, Pihlava JM, Jauhiainen L, Munyaneza JE and Vanhala P, Effects of carrot psyllid (Trioza apicalis) feeding on carrot yield and content of sugars and phenolic compounds. Ann Appl Biol 161:68-80 (2012)

46 Ökomonitoring 2002-2006. Ministerium für Ländlichen Raum und Verbraucherschutz, Abteilung Verbraucherschutz und Ernährung, Programm der Lebensmittelüberwachung Baden-Würtemberg, Stuttgart (2007)

47 Ökomonitoring 2007. Ministerium für Ländlichen Raum und Verbraucherschutz, Abteilung Verbraucherschutz und Ernährung, Programm der Lebensmittelüberwachung Baden-Würtemberg, Stuttgart (2007).

48 Miglioranza KSB, Aizpun de Moreno JE, Moreno VJ, Osterrieth ML and Escalante $\mathrm{AH}$, Fate of organochlorine pesticides in soils and terrestrial biota of 'Los Padres' pond watershed, Argentina. Environ Pollut 105:91-99 (1999).

49 Zohair A, Salim AB, Soyibo AA and Beek AJ, Residues of polycyclic aromatic hydrocarbons (PAHs), polychlorinated biphenyls (PCBs) and organochlorine pesticides in organically-farmed vegetables. Chemosphere 63:541-553 (2006)

50 Rashed A, Variation of bioactive constituents, sensory qualities and yield in carrots grown with different types of crop management. Thesis, School of Agriculture, Food and Rural Development, Newcastle University (2009).

51 Pferschy-Wenzig EM, Getzinger V, Kunert O, Woelkart K, Zahrl J and Bauer R, Determination of falcarinol in carrot (Daucus carota L.) genotypes using liquid chromatography/mass spectrometry. Food Chem 114:1083-1090 (2009).

52 Heinonen Ml, Carotenoids and provitamin-A activity of carrot (Daucus carota L) cultivars. J Agric Food Chem 38:609-612 (1990).

53 Bengtsson GB, Lea P, Seljåsen R, Berentsen E, Nilsen AN, Bjerke F, et al., Effect of soil type, fertilisation level and variety on sensory quality of carrots. INRA, CTIFL, INH, Section Nationale Carotte, 32nd Int. Carrot Conf., pp. 56 (2007).

54 Czepa A and Hofmann T, Quantitative studies and sensory analyses on the influence of cultivar, spatial tissue distribution, and industrial processing on the bitter off-taste of carrots (Daucus carota $\mathrm{L}$.) and carrot products. J Agric Food Chem 52:4508-4514 (2004).

55 Oborn I, Jansson G and Johnsson L, A field study on the influence of soil pH on trace element levels in spring wheat (Triticum aestivum), potatoes (Solanum tuberosum) and carrots (Daucus carota). Water Air Soil Pollut 85:835-840 (1995).

56 Rosenfeld HJ, Samuelsen RT and Lea P, The effect of temperature on sensory quality, chemical composition and growth of carrots
(Daucus carota L.). III. Different diurnal temperature amplitudes. Hort Sci Biotechnol 74:196-202 (1999).

57 Rosenfeld HJ, Samuelsen RT and Lea P, The effect of temperature on sensory quality, chemical composition and growth of carrots (Daucus carota L.).II. Constant diurnal temperatures under different seasonal light regimes. J Hort Sci Biotechnol 73:578-588 (1998).

58 Kimmer TW and Kozlowski TT, Ethylene, ethane, acetaldehyde, and ethanol production by plants under stress. Plant Physiol 69:840-847 (1982)

59 Lund ED and White JM, Polyacetylenes in normal and water stressed 'Orlando Gold' carrots (Daucus carota). J Sci Food Agric 51:507-516 (1990).

60 Lund ED and Bruemmer $\mathrm{JH}$, Acetylenic compounds in stored packaged carrots. J Sci Food Agric 54:287-294 (1991)

61 Middleton EM and Teramura $\mathrm{AH}$, The role of flavonol glycosides and carotenoids in protecting soybean from ultraviolet-B damage. Plant Physiol 103:741-752 (1993).

62 Taksdal G, Windbreak effects on the carrot crop. Acta Agric Scand B 42:177-183 (1992)

63 Makatouni A, The consumer message: what motivates parents to buy organic food in the UK? Results of a qualitative enquiry. Quality and Communication for the Organic Market, 6th IFOAM Organic Trade Conf., pp. 148-155 (1999).

64 Torjusen H, Sangstad L, O'Doherty Jensen K and Kjærnes U, European consumers' conceptions of organic food: a review of available research. Professional Report No. 4, National Institute for Consumer Research (SIFO), Oslo (2004).

65 Zanoli R, The European Consumer and Organic Food. School of Management and Business, University of Aberystwyth, Aberystwyth (2004).

66 Heaton S, Organic Farming, Food Quality and Human Health. A Review of the Evidence. Soil Association, Bristol (2001)

67 Woese K, Lange D, Boess C and Bogl KW, A comparison of organically and conventionally grown foods - results of a review of the relevant literature. J Sci Food Agric 74:281-293 (1997).

68 Dangour AD, Dodhia SK, Hayter A, Allen E, Lock K and Uauy R, Nutritional quality of organic foods: a systematic review. Am J Clin Nutr 90:680-685 (2009).

69 Smolen S and Sady W, The effect of various nitrogen fertilization and foliar nutrition regimes on the concentrations of sugars, carotenoids and phenolic compounds in carrot (Daucus carota L.) Sci Hort 120:315-324 (2009).

70 Rembialkowska E, Quality of plant products from organic agriculture. J Sci Food Agric 87:2757-2762 (2007).

71 Lauridsen C, Halekoh $\mathrm{U}$ and Jørgensen $\mathrm{H}$, Use of a rat model to elucidate impact of organic food on health. Eur. Joint Organic Congr., Odense, pp. 610-611 (2006).

72 Brandt K, Leifert C, Sanderson R and Seal JS, Agroecosystem management and nutritional quality of plant foods: the case of organic fruits and vegetables. Crit Rev Plant Sci 30:177-197 (2011).

73 Fjelkner-Modig S, Bengtsson $\mathrm{H}$, Stegmark R and Nystrom S, The influence of organic and integrated production on nutritional, sensory and agricultural aspects of vegetable raw materials for food production. Acta Agric Scand B 50:102-113 (2001).

74 Seal CJ and Brandt K, Nutritional quality of foods, in Handbook of Organic Food Safety and Quality, ed. by Cooper J, Niggli U and Leifert C. Woodhead, Cambridge, pp. 25-40 (2007).

75 Stracke BA, Rüfer CE, Bub A, Briviba K, Seifert S, Kunz C, et al., Bioavailability and nutritional effects of carotenoids from organically and conventionally produced carrots in healthy men. BrJNutr 101:1664-1672 (2008).

76 Jorgensen $\mathrm{H}$, Brandt $\mathrm{K}$ and Launidsen $\mathrm{C}$, Year rather than farming system influences protein utilization and energy value of vegetables when measured in a rat model. Nutr Res 28:866-878 (2008).

77 Haglund A, Johansson L, Berglund L and Dahlstedt L, Sensory evaluation of carrots from ecological and conventional growing systems. Food Qual Prefer 10:23-29 (1999).

78 Loncarevic S, Johannessen GS and Rorvik LM, Bacteriological quality of organically grown leaf lettuce in Norway. Lett Appl Microbiol 41:186-189 (2005)

79 Johannessen GS, Bengtsson GB, Heier BT, Bredholt S, Wasteson Y and Rorvik LM, Potential uptake of Escherichia coli 0157:H7 from organic manure into crisphead lettuce. Appl Environ Microbiol 71:2221-2225 (2005) 
80 Abdelnoor AM, Batshoun R and Roumani BM, The bacterial flora of fruits and vegetables in Lebanon and the effects of washing on the bacterial content. Zbl Bact Hyg I Abt Orig B 177:342-349 (1983).

81 DiPersio PA, Kendall PA, Yoon Y and Sofos JN, Influence of modified blanching treatments on inactivation of Salmonella during drying and storage of carrot slices. Food Microbiol 24:500-507 (2007).

82 Gutezeit B, Yield and nitrate content of carrots (Daucus carota L.) as affected by nitrogen supply. Acta Hort (ISHS) 506:87-92 (1999).

83 Shokrzadeh M, Shokravie M and Saedi Saravi SS, The measurement of nitrate and nitrite content in carrots and onions sampled from central cities of Mazandaran State of Iran. Toxicol Environ Chem 90:603-607 (2008).

84 Guerette V, Desjardins Y, Belec C, Tremblay N, Wier U and Scharpf $\mathrm{HC}$, Nitrogen contribution from mineralization of vegetable crop residues. Acta Hort 83:427-434 (2002).

85 Gennaro L and Quaglia GB, Food safety and nutritional quality of organic vegetables. Proc. Sixth Int. Symp. on Protected Cultivation in Mild Winter Climate: Product and Process Innovation, pp. 675-680 (2000).

86 Ren H, Takagi Y, Bao H, Goto S, Endo H and Hayashi T, Fluctuation of anti-mutagenicity of organically cultivated vegetables. J Jpn Soc Food Sci Technol 47:460-464 (2000).

87 Grinder-Pedersen L, Rasmussen SE, Bügel S, Jørgensen LV, Gundersen $V$ and Sandström B, Effect of diets based on foods from conventional versus organic production on intake and excretion of flavonoids and markers of antioxidative defense in humans. $J$ Agric Food Chem 51:5671-5676 (2003).

88 Kopsell DA, Barickman TC, Sams CE and McElroy JS, Influence of nitrogen and sulfur on biomass production and carotenoid and glucosinolate concentrations in watercress (Nasturtium officinale R. Br.). J Agric Food Chem 55:10628-10634 (2007).

89 Schulze W, Über den Einfluss der Düngung auf die Bildung der Choloroplastenpigmente. Z Pflanzenernar Düng Bodenkd 76:1 -19 (1957).

90 Benard C, Gautier H, Bourgaud F, Grasselly D, Navez B, Caris-Veyrat $C$, et al., Effects of low nitrogen supply on tomato (Solanum lycopersicum) fruit yield and quality with special emphasis on sugars, acids, ascorbate, carotenoids, and phenolic compounds. $J$ Agric Food Chem 57:4112-4123 (2009).

91 Battilani A, Manipulating quality of horticultural crops with fertigation. Proc. Fifth Int. Symp. on Irrigation of Horticultural Crops, pp. 47-59 (2008).

92 Biemond $\mathrm{H}$, Effects of nitrogen on accumulation and partitioning of dry matter and nitrogen of vegetables. 2. Leek. Neth J Agric Sci 43:435-446 (1995).

93 Hochmuth GJ, Brecht JK and Bassett MJ, Fresh-market carrot yield and quality did not respond to potassium fertilization on a sandy soil validated by Mehlich-1 soil test. Hort Technology 16:270-276 (2006).

94 Shibairo SI, Upadhyaya MK and Toivonen PMA, Potassium nutrition and postharvest moisture loss in carrots (Daucus carota L.). J Hort Sci Biotechnol 73:862-866 (1998).

95 Schlatter J and Luethy J, Vorkommen und Toxizitaet von Phytoalexinen in pflanzlichen Lebensmitteln. Mitt Gebiete Lebensmittelunters Hyg 77:404-419 (1986).

96 Ruhland M, Engelhardt G and Wallnofer PR, Transformation of the mycotoxin ochratoxin $A$ in plants. 2. Time course and rates of degradation and metabolite production in cell-suspension cultures of different crop plants. Mycopathologia 134:97-102 (1996).

97 Klaasen JA and Nelson PE, Fumonisin production by field strains of Fusarium nygamai (Gibberella nygamai) and ascospore progeny of laboratory crosses. World JMicrobiol Biotechnol 14:873-877 (1998).

98 Lairon D, Nutritional quality and safety of organic food. A review, in Sustainable Agriculture, Vol. 1, ed. by Lichtfouse E, Alberola C, Souchere V and Debaeke P. INRA, Paris, pp. 1-9 (2009).

99 Gives I, Baxter S, Minihane AM and Shaw E, Health Benefits of Organic Food: Effects of the Environment. CABI, Wallingford (2008).

100 Condon P, Kuc J and Draudt HN, Production of 3-methyl-6methoxy-8-hydroxy-3,4-dihydroisocoumarin by carrot root tissue. Phytopathology 53:1244-1250 (1963).

101 Goodliffe JP and Heale JB, Factors affecting the resistance of stored carrot roots to Botrytis cinerea. Ann Appl Biol 85:163-164 (1977).

102 Ökomonitoring 2011. Ministerium für Ländlichen Raum und Verbraucherschutz, Abteilung Verbraucherschutz und Ernährung,
Programm der Lebensmittelüberwachung Baden-Würtemberg, Stuttgart (2011).

103 Seljåsen R, Bengtsson GB, Hoftun H and Vogt G, Sensory and chemical changes in five varieties of carrot (Daucus carota L.) in response to mechanical stress at harvest and post-harvest. J Sci Food Agric 81:436-447 (2001).

104 Negi PS and Roy SK, Effect of low-cost storage and packaging on quality and nutritive value of fresh and dehydrated carrots. J Sci Food Agric 80:2169-2175 (2000).

105 Seljåsen $\mathrm{R}$, Hoftun $\mathrm{H}$, Selliseth $J$ and Bengtsson GB, Effects of washing and packing on sensory and chemical parameters in carrots (Daucus carota L). J Sci Food Agric 84:955-965 (2004).

106 Berger M, Kuchler T, Maassen A, Busch-Stockfisch M and Steinhart H, Correlations of carotene with sensory attributes in carrots under different storage conditions. Food Chem 106:235-240 (2008).

107 Rocha A, Mota C and Morais A, Effects of minimal processing and temperature on respiration rate of carrot (cv. 'Nantes'). Proc. 5th Int. Postharvest Symp., pp. 1967-1970 (2005).

108 Soria AC, Olano A, Frias J, Peñas E and Villamiel M, 2-Furoylmethyl amino acids, hydroxymethylfurfural, carbohydrates and $\beta$ carotene as quality markers of dehydrated carrots. J Sci Food Agric 89:267-273 (2009).

109 Lentz CP, Moisture loss of carrots under refrigerated storage. Food Technol 20:201-224 (1966).

110 Shibairo SI, Upadhyaya MK and Toivonen PMA, Postharvest moisture loss characteristics of carrot (Daucus carota L.) cultivars during short-term storage. Sci Hort 71:1-12 (1997).

111 Seljåsen R, Hoftun $\mathrm{H}$ and Bengtsson GB, Sensory quality of ethyleneexposed carrots (Daucus carota L, cv 'Yukon') related to the contents of 6-methoxymellein, terpenes and sugars. J Sci Food Agric 81:54-61 (2001).

112 Carlton BC, Peterson CE and Tolbert NE, Effects of ethylene \& oxygen on production of a bitter compound by carrot roots. Plant Physiol 36:550-552 (1961).

113 Chalutz E, Devay JE and Maxie EC, Ethylene-induced isocoumarin formation in carrot root tissue. Plant Physiol 44:235-241 (1969).

114 Kato-Noguchi $\mathrm{H}$, Effects of a low oxygen atmosphere on lactic fermentation in shredded carrot root tissues. J Plant Physiol 152:368-371 (1998).

115 Perata $P$ and Alpi A, Ethanol metabolism in suspension cultured carrot cells. Physiol Plant 82:103-108 (1991).

116 Iqbal T, Rodrigues FAS, Mahajan PV and Kerry JP, Mathematical modeling of the influence of temperature and gas composition on the respiration rate of shredded carrots. J Food Eng 91:325-332 (2009).

117 Ziman L, Srobarova A and Jedryczka M, The biodiversity of the fungus Sclerotinia sclerotiorum. Biologia 54:25-32 (1999).

118 Van den Berg $L$ and Lentz CP, Effect of temperature, relative humidity, and atmospheric composition on changes in quality of carrots during storage. Food Technol 20:104-107 (1966).

119 Apeland $\mathrm{J}$ and Baugerod $\mathrm{H}$, Factors affecting weight loss in carrots. Acta Hort 20:92-97 (1969).

120 Pospisil J, Marjanovic M and Magdalenic B, The influence of packaging in polyethylene bags on the shelf-life of grated carrot, Conference: Agriculture, Food Chemistry and the Consumer, Versailles, 27-29 Sep. Vol. 1, ed. by. University of Zagreb, Zagreb, pp. 82-86 (1989).

121 Artes F, Innovations in physical modulated treatments for preserved postharvest quality of fruits and vegetables. 3. Gaseous treatments. Rev Esp Cienc Tecnol Alim 35:247-269 (1995).

122 Afek U, Orenstein J and Nuriel E, Steam treatment to prevent carrot decay during storage. Crop Protect 18:639-642 (1999).

123 Barry-Ryan Cand O'Beirne D, Effects of peeling methods on the quality of ready-to-use carrot slices. Int J Food Sci Technol 35:243-254 (2000).

124 CFSAN/Office of Plant and Dairy Foods, Exploratory Data on Furan in Food. US Food and Drug Administration, Silver Spring, MD (2004).

125 Duan $\mathrm{H}$ and Barringer SA, Changes in furan and other volatile compounds in sliced carrot during air-drying. J Food Process Preserv 36:46-54 (2012).

126 De Belie N, Laustsen AM, Martens M, Bro R and de Baerdemaeker $\mathrm{J}$, Use of physico-chemical methods for assessment of sensory changes in carrot texture and sweetness during cooking. J Texture Stud 33:367-388 (2002).

127 Miglio C, Chiavaro E, Visconti A, Fogliano V and Pellegrini $\mathrm{N}$, Effects of different cooking methods on nutritional and 
physiochemical characteristics of selected vegetables. J Agric Food Chem 56:139-147 (2008).

128 Fenton F, Tressler DK, Champ SC and King CG, Losses of vitamin C during boiling and steaming of carrots. J Food Sci 3:403-408 (1938).

129 Nyman EMGL, Svanberg SJM, Andersson R and Nilsson T, Effects of cultivar, root weight, storage and boiling on carbohydrate content in carrots (Daucus carota L). J Sci Food Agric 85:441-449 (2005).

130 Perez-Galvez A, Rios JJ and Minguez-Mosquera Ml, Thermal degradation products formed from carotenoids during a heatinduced degradation process of paprika oleoresins (Capsicum annuum L.). J Agric Food Chem 53:4820-4826 (2005).

131 Homero-Mendez D and Minguez-Mosquera Ml, Bioaccessibility of carotenes from carrots: effect of cooking and addition of oil. Innovat Food Sci Emerg Technol 8:407-412 (2007).

132 Ölmez H and Särkkä-Tikkonen M, Case Study: Assessment of Chlorine Replacement Strategies for Fresh Cut Vegetables. FiBL, Frick (2008).

133 Alegria C, Pinheiro J, Goncalves E, Fernandez I, Moldao M and Abreu $\mathrm{M}$, Evaluation of a pre-cut heat treatment as an alternative to chlorine in minimally processed shredded carrot. Innovat Food Sci Emerg Technol 11:155-161 (2010).

134 Pathanibul P, Taylor TM, Davidson PM and Harte F, Inactivation of Escherichia coli and Listeria innocua in apple and carrot juices using high pressure homogenization and nisin. Int J Food Microbiol 129:316-320 (2009).

135 Hof KHV, West CE, Weststrate JA and Hautvast JGAJ, Dietary factors that affect the bioavailability of carotenoids. J Nutr 130:503-506 (2000).
136 Rock CL, Lovalvo JL, Emenhiser C, Ruffin MT, Flatt SW and Schwartz SJ, Bioavailability of $\beta$-carotene is lower in raw than in processed carrots and spinach in women. J Nutr 128:913-916 (1998).

137 Yaylalan VA, Precursors, formation and determination of furan in food. J Verbr Lebensm 1:5-9 (2006).

138 Bakhiya N, Appel KE. 2010. Toxicity and carcinogenicity of furan in human diet. Archives of Toxicology 84(7):563-78.

139 Chen L-J, Hecht SS and Peterson LA, Identification of cis-2-butene1,4-dial as a microsomal metabolite of furan. Chem Res Toxicol 8:903-906 (1995).

140 Seidel K, Quality Aspects of Processed Organic Baby Food. FiBL, Frick (2008).

141 Lachenmeier $\mathrm{D}$, Reusch $\mathrm{H}$, Kuballa T. Risk assessment of furan in commercially jarred baby foods and insights into furan occurrence and formation in freshly home-cooked foods for infants and young children. Food Add Contaminants 26, 06 776-785 (2009).

142 Roux S, Courel M, Ait-Ameur L, Birlouez-Aragon I and Pain J-P, Kinetics of Maillard reactions in model infant formula during UHT treatment using a static bath ohmic heater. Dairy Sci Technol 89:349-362 (2009).

143 Acharid A, Rizkallah J, Ait-Ameur L, Neugnot B, Seidel K, SärkkäTikkonen $\mathrm{M}$, et al., Potential front face fluorescence as a monitoring tool for neoformed compounds in industrially processed carrot baby food. LWT - Food Sci Technol 49:305-311 (2012). 